\title{
The
}

Composition and Historical Value of

$$
\text { Ezra-Nehemiah. }
$$

By

Dr. Charles C. Torrey

\section{BSI355 4.T69}




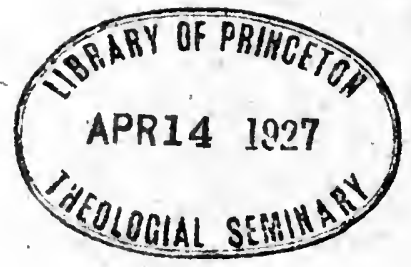

Division

Section 


\section{Beihefte}

zur

Zeitschrift für die alttestamentliche Wissenschaft.

II.

$\rightarrow$

The

Composition and Historical Value of

Ezra-Nehemiah.

By

\section{Dr. Charles C. Torrey}

Instructor in the Semitic Languages at Andover Theological Seminary.

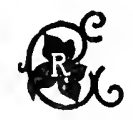

Giessen

J. Ricker'sche Buchhandlung I $\$ 96$. 


\author{
The
}

\title{
Composition and Historical Value
}

\author{
of \\ Ezra-Nehemiah.
}

By

\section{Dr. Charles C. Torrey}

Instructor in the Semitic Languages at Andover Theological Seminary.

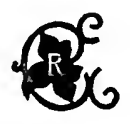

Giessen

J. Ricker'sche Buchhandlung

I 896. 
, 


\section{CONTENTS:}

I. The Composition

A. Analysis of Ezra I-6. . . . . p. +

B. The Source of Ezra 7-10, Neh. 8-io p. It

C. The Original Position of Neh. $7,70^{1}-8$, I $8 ; 9,10 \ldots \ldots$

D. The Chronicler's Share in Neh, I-7 . . p. 35

E. The Origin of Neh. I I-I3... . p. +2

Table of the Analysis. . . . . . . . . p. 49

2. The Historical Value . . . . . . . p. 5I 


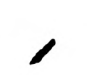




\section{The Composition of the Book.}

It is at present generally agreed that Chr.-Ezr.-Neh. originally formed one book, which was put in its final form by the author of the book of Chronicles, commonly called "the Chronicler". It is also agreed that a not inconsiderable part of the Ezra-Nehemiali history was composed by this same writer. The portions thus ascribed to him by common consent are (with slight variations): Ezr. I. 3. 4, I-5. 24 (Aramaic); 6, I6-22 (partly Aramaic); 7, I-IO; 8, 35. 36; Neh. I2, I-26. 44-47. Many of the foremost critics add Ezr. 7, 12-26; Neh. I 3, I-3.

In nearly or quite all of these passages believed to have been written by the Chr., he is supposed to have been using older documentary sources; not because this is made probable by anything in the passages themselves, or because the Chr. has the reputation of being a trustworthy historian, - the reverse is the case, - but because he seems to have preserved in the book Ezr.-Neh. at least three documents that give valuable information concerning the history of the period; namely, the personal memoirs of Ezra and Nehemiah, and a document written in Aramaic dealing with events connected with the building of Jerusalem, and especially the temple. From these sources, which he generally reproduces verbatim, he is supposed to have derived the information given in his own words.

I think it can be shown that the Chr.'s written sources are represented only by the following sections: I. Ezr. 
4, 8-6, 14, a free composition in Aramaic; 2. Neh. I. 2. 3, 33-6, 19, the authentic Memoirs of Nehemiali. It will appear that we have no reason to suppose that any other sources, written or oral, were used by the Chr. In particular, he is seen to have been the sole author of the supposed "Memoirs of Ezra".

Attention has recently been called anew to the literary and historical problems of Ezr.-Neh., chiefly through the controversy between van Hoonacker and Kuenen (is90-IS92), and that between Kosters and Wellhausen (IS93-1S95). Van Hoonacker ${ }^{\mathrm{I}}$ attempted to prove that Neh.'s career falls in the reign of Artaxerxes I.; that of Ezra in the reign of Artaxerxes II. Kuenen, in his reply ${ }^{2}$, defended the generally accepted view. The elaborate investigations of Kosters require especial mention here. In his Hersicl van Israel in het Porische Tijdvak (Leiden, I 893) ${ }^{3}$, he reaches the following chief conclusions: I. The narrative contained in Ezra $\mathrm{I}-4$ is untrustworthy; even the return of exiles under Cyrus is disproved by other evidence. 2. The Aramaic portion of Ezra is the work of three different authors; $4,8-24$ he assigns to the Chronicler, while in 5. 6 he concludes that we have two separate documents united by a redactor. 4 3. Ezra and the company that returned with him are to be given greater

I Néhimie et Esitras. Louvain, 1890 . Also (in reply to Kuenen): Néhémie en l'an 20 d'Artax. I., Esdras en l'an 7'Artax. II. Gand, IS92; Zorobatel et le Second Temple. Gand, ISg2.

2 De Chronologie van het Peraische Tijdeak. Amsterdam, I89o. (Trans. in Gesammelte Abhandlungen, 1894, p. $212 \mathrm{ff}$.)

3 Trans. by Basedow, Dic Wickirherstellung Israels. IIeidelberg, 1 \$95. I have seen only this translation. Kosters has also published a reply to Wellhausen in the Theol. Tijdschr., 1895, p. $5+9 \mathrm{ff}$.

4 This strange theory is disposed of by Wellhausen in his reply to Kosters (sce below), p. 176. 
prominence than ever in the history of Jerusalem. 4. The original order of the narrative is to be restored as follows: Neh. I, I-7, 5; II, 3-36; I2, I-26; I I, If.; I 2, 27-43. 44-47; 13, 4-3I; Ezr. 7-IO; Neh. 9; 10; 13, I-3; $7,6-8$, Is. The disturbance of this order in our present text is due, not to accident, but to the deliberate purpose of the redactor. Kosters' conclusions as to the composition of the Ezra-Neh. part of the narrative do not differ materially from those of other critics. He believes that we have here, in the main, trustworthy history.

The most valuable part of Kosters' work is his examination of the evidence relating to the restoration under Cyrus. ${ }^{1}$ He argues with force that the testimony in its favor is limited to the Chr.'s statements; and shorvs that the prophets Haggai and Zechariah, as well as Ezra 5. 6, know nothing of such a return of exiles. As for Kosters' treatment of the history of Ezra and Nehemiah, it is not so easy to feel confidence in it. His restored order of the text is not justified even by his own hypothesis (l. c., p. II $6 \mathrm{f}$.), which is itself improbable enough. Moreover, his whole theory falls to the ground unless he is allowed to cancel or deny the date given in Ezr. 7, 7. 8. So he limself acknowledges (p. I I5). His attempt to get rid of the difficulty is courageous, but by no means successful. The same may be said of his treatment of the date in Nel. 9, I (p. 85); and there are many examples of arbitrary dealing with the text, some of which will be noticed below. His work well illustrates the difficulties into which a thorough-going historical criticism of Ezra-Neh. will bring the man who tries to take the Ezra narrative seriously.

I Wiederherstellung, p. $17 \mathrm{~m}$. 
Wellhausen, in his reply to Kosters ${ }^{\mathrm{I}}$, maintains the generally accepted view of the post-exilic history; though making certain concessions ${ }^{2}$ in the matter of the return under Cyrus, and in regard to the possibility that Ezra's work in Jerusalem may have followed that of Neh., as claimed by Kosters.

$$
\text { A. Analysis of Ezra } 1-6 \text {. }
$$

As the present investigation is concerned chiefly with the part of the book relating to Ezra and Nehemiah, I shall not attempt here to discuss at length the portion contained in ch. I- 6 . The problems connected with the question of its original extent and form are complicated and interesting, involving especially the inquiry into the relation of I Esdras to our canonical Ezra. I shall endeavor to omit here all that is not essential to my present purpose, reserving for another time the further investigation of these first six chapters. ${ }^{3}$

Ezra I ff. is the continuation of Chronicles, by the same writer, as external and internal evidence combine to show. In one (the canonical) form of the text, the two books overlap each other by several verses; in the other (I Esdras), by two whole chapters. Moreover, the very noticeable peculiarities of the Chr. narrative continue to show then-

I Die Rückkehr der Fuden aus dem babyl. Exil. (Nachrichten d. Königl. Gesellsch. d. Wissenschaften zu Göttingen, 1S95, p. I66-IS6).

2 L. c., P. $1 \mathrm{~S}_{5} \mathrm{f}$.

3 I hope to show in particular, if I have opportunity: 1. That 1 Esdras exhibits in these six chapters a version somewhat nearer to the archetype than our Ezra; and that it is throughout its whole extent of the greatest importance for restoring the original text. 2. The Story of the Tliree Pages, which is a secondary addition to the book, was written in Aramaic. 3. The original form of this part of the narrative, from Cyrus to Ezra, can be ascertained with practical certainty. 
selves in Ezra; the style also (one of the most strongly marked of any in the O. T.) is the same. These arguments were set forth in a convincing way by Zunz, Die' gottesdienstlichen Vorträge der Fudcn, I832, p. $21 \mathrm{ff}$., and have been repeated many times since. It is now generally agreed that ch. I ; $3 ; 4, \mathrm{I}-5.24 ; 6, \mathrm{I} 6-22$ were written wholly by the Chronicler, whatever may have been his sources.

Ch. 2, which contains the list of those who came up from Babylon with Zerubbabel, has been generally left out of the discussion, because of the prevailing belief that it was either borrowed from Neh. 7, or else, like the corresponding portion of that chapter, taken from the older source that seems to be mentioned there (vs. 5). I think it will not be difficult to show that this chapter also, like the preceding and following, is from the hand of the Chronicler. Obviously, the argument should begin with an examination of the passage in its context in the book of Nehemiah. As this can be done better in connection with the investigation of that book, and as some facts having an important bearing on the question will come to light in course of the study of the Ezra narrative, I will reserve the discussion until Neh. 7 is reached.

With 4,8 begins the long Aramaic section, extending to the end of 6,18 . This contains: I. an account of how the building of Jerusalem was hindered by enemies of the Jews, in the reign of Artaxerxes; 2. an account of the building and finishing of the temple in the reign of Darius. To the first part of this Aramaic section the editor prefixed a brief introduction of his own (vs. $6 \mathrm{f}$.) ${ }^{\mathrm{x}}$, which through

I Vs. 6 is simply a historical patch, inserted by the Chr. to make the history continuous (see below), and also to account for the inactivity of the Jews (cf. vs. 5). 
scribal blunders has become entangled with the beginning of the following document.

Until vs. 8 there is no trace of an Aramaic source. The document which there begins was in any case a piece of narrative (cf. vs. 23), and probably began with the word אד. Vs. 7 ("in the days of Artaxerxes") was, in all probability, in its original form an introduction to the Rehum-Shimshai correspondence which follows. As it now reads, it is of no possible use to anybody. Vs. S-II, as they now stand, present a scene of the wildest confusion.

The simplest solution of this tangle is to suppose that the names in vs. 7 originally stood in vs. 6 ; and that their accidental omission there, and insertion at the next opportunity, caused further displacement. The original form of the text would then have been the following: ובמלכות מלות (6)

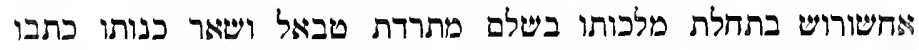

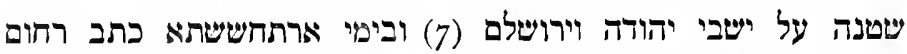

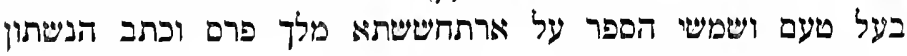

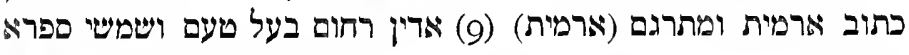

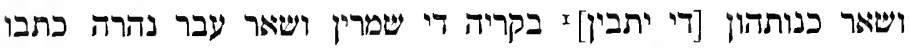

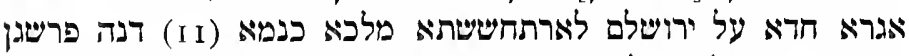

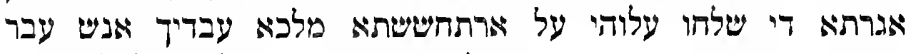

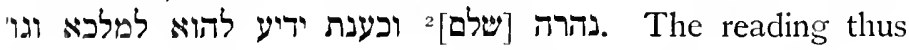
gained is unobjectionable, and quite in the style of $5,5 \mathrm{~b}-7$. The Massoretic text differs from this only in a displacement of clauses which may be explained on the supposition that a copyist accidentally omitted the names in vs. 6 , and noticing his mistake after he had begun vs. 7 , tried to

I $\Lambda$ s in vs. I7. It is probable, however, that the Chr. himself introduced the list of names here.

2 This word can hardly have been omitted. 
repair it. This hypothesis appears to me to account for all the facts in a simple and natural way. ${ }^{\mathrm{T}}$

The grotesque list of names in vs. 9b. Io may possibly have belonged to the original form of the letter, though this does not seem probable. On the other hand, its insertion here is so exactly in accord with the taste and habit of the Chr. that we may conclude with some confidence that he was its author.

Vs. 24 of this chapter is generally assigned to the Chronicler, for two reasons: I. Xerxes and Artaxerxes (4,6-23) are out of place between Cyrus ( $1.3, \mathrm{I}-4,5)$ and Darius I., to whose reign the events narrated $\mathrm{n}$ ch. $5 \mathrm{f}$. are supposed to belong. In other words, ch. 5 cannot be the sequel of 4, 6-23. To this it may fairly be replied, that the assumption upon which this objection is based, that the Chr.'s Aramaic source contains trustworthy history, has nothing to support it. The arguments commonly employed against the genuineness of the Cyrus edict in ch. $\mathrm{I}^{2}$ are equally applicable here. The utterances recorded in 4, ig f. would be remarkable indeed in the mouth of a Persian king, but viewed as a familiar product of Jewish literature they are quite in their proper place. ${ }^{3}$ It is to be noticed that these

I I Esdr. 2, $15 \mathrm{f}$. is palpably an attempt to bring order out of the chaos of our Massoretic text. Notice especially the combining of the

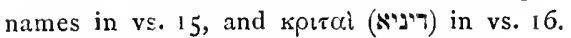

2 See e. g. Stade, Gesch., II. p. 99.

3 Cf. Graetz, Gesch. der Fuden, II. p. 10o. Kosters, op. cit., p. 54 ff., calls in question the historical character of Ezra 4, 8-23, on the ground that the wording of the alleged correspondence shows it to be fictitious, and that the building of the city wall at this time is improbable, in view of known facts. His arguments are not all valid, to be sure. 4, 9b. Io is probably an interpolation, as he himself admits. The conclusion drawn from vs. 2 I (last clause) is quite arbitrary and (as it seems to me) unjustified. The attempt to prove that the work of building the wall cannot have been begun at this time (p. $5^{8 \mathrm{f}}$.) concerns only those 
verses are the centre of the whole episode; if this part of the correspondence is not genuine, the historicity of the rest cannot be maintained. In ch. $5 \mathrm{f}$. the same features appear again; and the more such indications accumulate, the plainer the conclusion. Ch. 5,8 . I I-I6; 6, 3-5. 8-I 2 are clearly Jewish compositions couched in the usual stock phrases, and not for a moment to be regarded as actual deliverances of Syrian officials and a Persian king. From the whole tone and atmosphere of this Aramaic section, from beginning to end, it must be plain that it contains, not a series of remarkable utterances by heathen kings and officers to the glory of the Jews and their religion, but a kind of literature that abounds during this period of Jewish history. So far as historical value is concerned, Ezra 4, 8-6, I 5 stands in all respects on the same plane with Dan. 2-6 and the book of Esther.

There is therefore nothing improbable in the order Cyrus, ...?..., Artaxerxes, Darius. There is no reason to suppose that Jewish historians and story-tellers of the Greek period ${ }^{x}$ were accurately informed as to the order and chronology of the Persian kings. The author of Dan. 5. 6 made Darius I. precede Cyrus; it is probable that the Chr. shared this view. ${ }^{2}$ The only thing that need occasion

who make the very doubtful connection with Neh. Iff. The bare statement that the Jews began to build the wall in the days of a king named Artaxerxes, and were soon hindered by enemies, contains nothing at all improbable. The single one of Kosters' arguments that is convincing is that derived from the mention of the "book of the records" (p. 57). This he passes over too hastily.

I See Nöldeke, Die altest. Literatur, p. 64. I shall touch later on the question of the date of this Aramaic document.

2 If we suppose this to have been the case, the history, so far as he secords it, moves along in steady course and without a hitch: Cyrus, Xerxes, Artaxerxes I., Darius II., Artaxerxes II., Darius III. (Neh. 12, 22). 
surprise is, that in view of the bewildering succession of kings named Darius and Artaxerxes, these writers seem to have made so few mistakes.

2. The second reason for ascribing 4,24 to the Chr. has greater weight. The Aramaic portion vs. $8-23$ speaks only of the building of the city, and in particular, of the city walls; but in vs. 24 mention is made only of the building of the temple, with which the preceding narrative of the Chr., 3, $S-4,5$, has been concerned. The natural conclusion is that the Chr. wrote vs. 24 as a harmonistic patch, to make the Aramaic narrative fit into his own. It may be argued, with some appearance of plausibility, that the enemies of the Jews would in any case represent to the king that the city walls were being built, but would have no occasion to mention the temple, inasmuch as he could have nothing to apprehend from its completion. But this argument is far from satisfying, especially in view of ch. 5. The fact, moreover, that we have in these letters the words of the Jewish narrator, who would hardly refrain from all mention of the temple in such a place, makes it pretty certain that the narrative that originally stood immediately before vs. $8-23$ was not concerned especially with the building of the temple. It follows that we are indebted to the Chr. for vs. 24. Further proof of this may perhaps be found in the use of the expression מלך פרס, which has been recognized since Ewald as the favorite

It is not easy to believe that the Chr. regarded the Artaxerxes who befriended Ezra and Nehemiah as identical with the one named in Ezra 4. Had he done so, it would have been an easy matter to transpose the account of the Artaxerxes correspondence, putting it at the end of ch. 6 , or just before Neh. I. The Massoretic tradition, which writes the name of the former invariably with $D$, the latter invariably with $ש$, belongs to the same view of the history. 
form with this writer.' (Schrader), or בהזין (König), is hardly permissible.

In chapter 6 , vs. 9 f. is an interpolation by the Chr., as appears from a comparison of vs. 17; 7, 17.22; 8, 35; cf. further I Chr. 29, 21; 2 Chr. 29, 21. 22. 32; 2, 9. 14 (not in Kings), \&c.; and from the use of the favorite ביום

It has long been recognized that in vs. 14, at least the

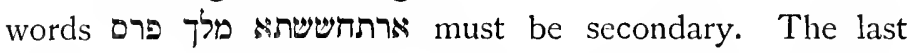
two words suggest the Chr., and the blundering mention of Artaxerxes is quite as likely to be due to him as to any later hand. Schrader ${ }^{2}$ probably goes too far in claiming the whole half-verse $14 \mathrm{~b}$ for this writer; the statement, "they built and finished .... according to the dccrce of Cy'rus and Darius", is the necessary conclusion of the preceding narrative; it was in order to show this very thing that the whole account was written. V's. 15, on the other hand, may well be assigned to the Chr. It is evidently an important part of his purpose to fix the exact dates, all through this history; cf. 3,6. 8 (where I Esdras 5, 54 f. has preserved the true reading); 6,$19 ; 7,9$, \&c. The reason for choosing this particular date here is plain from vs. 19.22; cf. Ex. 12, 2 ff. Accordingly, all the latter part of the chapter, from the last clause of vs. I4, is to be assigned to this writer.

Aside from the passages already noticed (4, 6.7.9b. I0a. $24 ; 6$, 9. 10. $14 \mathrm{~b} \gamma-18$ ), there is no certain trace of the Chr. in the Aramaic section, and no good reason for believing that he made any further additions or alterations.

I It is in fact used only by him. He generally employs it in speaking of Cyrus $(1,1.2 . S ; 3,7 ; 4,3.5)$, Darius $(4,5.24)$, and Artaxerxes $(4,7 ; 6,14(?) ; 7,1)$. Similarly מלד במל, Neh. I3, 6.

2 Slud. u. Krit. 1S67, p. 476 . 
The theory, suggested by Kosters ${ }^{\mathrm{r}}$, that he is the author of $4,8-23$, is as unlikely as possible. The only conceivable reason why he should compose and introduce at this point a document relating to the building of the walls, is the one clearly set forth by Kosters himself (ibid., p. 62). But if the Chr., having finished his story of the beginning of the temple, had wished to give a "similar representation" of the zeal of the returned Jews in building the city wall, he could not have defeated his own purpose more completely. The proximity of vs. 5 would nullify his attempt at the start, and vs. 24 would give it the coup de grâce. The omissions would be stili more remarkable. No better proof of this is needed than is furnished by Kosters' own train of reasoning (ibid.), in which he sets forth clearly the things that the writer must have said-none of which stand in our text! One gets the impression that Kosters has not read Ezra 4 recently. It would be much easier to believe that the Chr. was the author of $5,1-6,14$; but to this supposition also there are serious objections. Passages composed by him are generally easy to recognize, even when they are written in Aramaic. Thus in 7, 12-26, seven of the fifteen verses contain words or expressions unmistakably characteristic of him. It is hardly credible that he could have so completely veiled his identity in $5, \mathrm{I}-6$, I 4 , if he were the author, or even the reviser, of that portion. It is noticeable, too, that in 5, I. 2. 5, \&c. prophets and elders are mentioned, instead of priests and Levites and chief of the fathers; that in 5, שריו 2 is used without any reference to the former beginning made by these same men $(3,8)$; that in $5,14-16$ so little notice is taken of the narrative in ch. $1-3$; that $6,3.4$ has nothing in those chapters to which

I $O p$. cit., p. 6I ff., I I6. 
it can refer. On the whole, it seems quite as unlikely that the Chr. wrote or rewrote $5, \mathrm{I}-6, \mathrm{I} 4$ as that he was the author of $4,8-23$.

Further questions that arise concerning these two Aramaic passages-whether they originally belonged to the same document, and whether they formed there a continuous passage-need not be discussed here. I will merely state my own conviction, that they were written by the same hand, and that they stand here in their original order. $^{x}$

Before leaving Ezra $\mathrm{I}-6$, the fact should perhaps be emphasized that the Chr.'s narrative here is homogeneous thoughout, so far as the most careful examination can show. There are nowhere any marks that would indicate an older source behind his version of the history. ${ }^{2}$

I It is not even necessary to suppose that any intervening narrative was omitted by the Chr., if the date in I Esdr. 6, I (=Ezra 5, I) is original. It might easily have fallen out; cf. the Syr. Hex.

2 To this statement 3,3 is no exception. It is well known that the text of this passage is corrupt; and if Graetz' emendation (Monatschrift, $\mathrm{I} 875, \mathrm{p} .6 \mathrm{f}$.) were to be accepted, there would be reasonable ground for supposing that here, at least, the Chr. was not writing independently, in view of his customary treatment of the עמי הארץ. Graetz emends mainly in accordance with I Esdras, but makes of the second clause: "for all the peoples of the land came (באים instead of (באימה (ויחזקi) them." But against this emendation may be said: I. It overlooks the significant variations in the other versions of I Esdr.; particularly the Syr. Hex. 2. It involves a double mention of the "peoples of the land", the one statement conflicting with the other ("some of ... all of ..."). 3. The word (M. T. באימה) is as well attested as possible, and is just what we should expect here (cf. 4, If.). 4. The clause עיעלו עליי is now deprived of its connection with the preceding. 5מי הארצות -5 עלי (is one of the Chr.'s most characteristic expressions; and it is quite impossible that he should speak of these "peoples" in such a way as this (see below).

I would submit the following, as a plausible solution: 
The theory has occasionally been advanced that Ezr. I. 3 were originally written in Aramaic; i. e., that they formed a part of the "Aramaic Document." Thus van Hoonacker, Zorobabel, p. IO4-ir4. Howorth, in The Academy', Feb. 4, I \$93, makes the claim for Ezr. I. Van H. alone has attempted to bring forward proof in support of this (ibid.), but fails conspicuously.

On the other hand, there have been found advocates of the theory that Ezr. 5, I-6, I 5 is a translation from the Hebrew. Thus Schrader, Einlitung (De Wette), I 869 , p. $3^{87}$; Kosters, IVicderherstcllung; p. 62; see also Renan, Histoire, vol. IV. I 893 , p. 3. This theory not only lacks internal support in the chapters themselves, but is, it seems to me, quite untenable in view of the facts stated above.

As for the date of the Aramaic Document, all the indications seem to point to a time not long before that of the Chr. Nöldeke (Die alttest. Literatur, p. 64) assigned it to the Greek period, on internal grounds. If Graetz (Gesch. II. p. 85) is right in supposing that the writer of

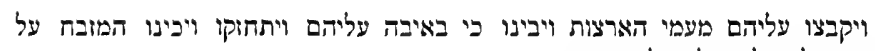

מבונתו ויעלו עליי עלות לייו וגונות

"And some of the peoples of the land gathered themselves together against them; and when they perceived that they were come with hostile purpose, they withstood them, and built the altar in its place, and offered.." sc.

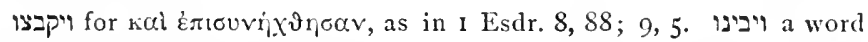
that the Chr. is especially fond of using. By confusion with ויכי ויבו all this trouble arose. Pinnl for kai katioxvoar; Syr. Hex. a)wllo. It is plain from the verss, that this verb had no direct object expresserl. For the idea expressed here, cf. 2 Chr. 13,7 , where the same verbs are used. The words "all the nations that are upon the earth" ( 1 Esdr.) were probably a gloss, judging from the fact that they are inserted in four different ways in the several versions. Notice, however, the evidence of dittography, the words:

עליהם מעמי הארצות ייבינו (ויכינו)

being written twice. 
this story of the correspondence with the Persian king had in mind the Samaritans (שמר in 4, 17), this may be taken as additional evidence.

\section{B. The Source of Eara 7-Io, Nelt. 8-Io.}

With chap. 7 begins the portion of the book supposed to have been written by Ezra himself. It consists of two sections: I. the account of Ezra's expedition from Babylon to Jerusalem $(7.8) ; 2$. the expulsion of the heathen wives (9. IO). But not all of this can be attributed to Ezra, as many critics have remarked. Ch. 7, I-IO, for example, is pronounced by nearly all to be from the hand of the Chronicler. Ch. S, $35 \mathrm{f}$. and the whole of ch. Io were also written by him "on the basis of Ezra's Memoirs." I Nor is this all. The letter of Artaxerxes, 7, II-26, is excluded by Cornill (p. 26I f.) from the supposed writings of Ezra, for reasons that are conclusive. ${ }^{2}$ There is left the portion 7, 27-8, 34; 9, I-I5; concerning which Cornill remarks that it bears throughout the impress of the same hand and the same spirit, and that there can be no doubt whatever that we have here the untouched narrative of Ezra himself.

But to go so far, and no further, is to get into very serious difficulties. The statement just quoted concerning the homogeneous character of Ezra 8.9 is only misleading unless it is extended to include chaps. 7.10, and the passage Neh. 7, 73-10, 40, now generally recognized as belonging to the Ezra document, and standing on the same footing with Ezra Io. Absolutely the only reason for separating

I Zunz, Gottesd. Vorträge, p. 28; Driver, p. 517; König, Einl., P. 2SIff.; Kosters, Wiederherstellung, p. 9Sff., \&c.

2 So Ewaid, Nü'dekc, Knenen, Kosters, Driver, al. 
out the two chaps. Ezra 8.9 as "untouched" is the fact that they are written in the first person instead of the third. Just how much weight this fact should have, we may be better able to judge by and by. The material contained in these seven chapters is thoroughly homogeneous, and bears the marks of a single author; but it is the same hand and the same spirit that appear no less plainly in Ezra I-6. It is the Clironicler, and he alone, whose work can be discerned here. And the indications are truly unmistakable. His own favorite ideas, and even his most characteristic expressions, are to be seen in these chapters, if anywhere; not in a few piaces, but in many. The fact could hardly fail to have been generally recognized, if it were not for the time-honored ideas concerning the importance of Ezra in the post-exilic history. ${ }^{x}$

It will be well worth while to examine the "Iclistuick" Ezra 7, 27-9, 15 in regard to its vocabulary and style, with a view to comparing it with the writings known to have been composed by the Chronicler; and then, if a satisfactory result is reached, to apply the same test to other doubtful portions of the narrative. The argument based on the material content of the chapters in question is quite as weighty as that derived from the language; but the latter will be found to furnish the best possible starting point.

The vocabulary of Ezra-Nehemiah, or of some portion of it, has not infrequently been made the subject of examination, more or less thorough; e. $g$. by Zunz, l. c., p. 2 I ff.; De Wette-Schrader, Einl., I\$69, p. 384 ; Graf, Gsschichtl. Büchor, passim; Kuenen, Onderwock ${ }^{2}$, p. 448f., 510f.; Driver, Introd., p. 502-507. Of some of these investigations

I Due largely to the figure which he cuts in later Jewish tradition. 
I shall have more to say later. The lists which I present here do not claim to be exhaustive, but to be trustworthy so far as they go. Of course in any such comparison as this the force of the argument is cumulative; indications that would have little or no weight by themselves may become of great moment when combined. After making all due allowance for resemblances in style and vocabulary such as might be accounted for on the supposition of two writers moving in the same circle of ideas, or representing the same stage in the history of the language, there will still be found so many and so striking correspondences as to make the procf complete. ${ }^{\mathrm{x}}$

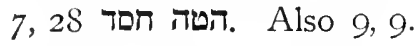

יעצי The ministers of the king. Used in this technical sense only I Chr. 27, 33; Ezra 7, I4. 15 (Aramaic); S, 25. Cf. also 4,5 .

ולכל. Giesebrecht, Dic Pracposition Lamed, p. Io8, cites this passage and I Chr. 26, 26; 28, I. $21 ; 29,6 ; 2$ Chr. 26, 14 as forming a class by themselves. See further notes below on the peculiar use of this preposition by the Chr.

התחזקת. This Hithpa el is used frequently (fifteentimes) ${ }^{2}$ by the Chronicler; only one other O. T. writer ( $\mathrm{J}$ in Samuel) uses it as often as three times.

Also 8, is.

S, I התיחשם. A favorite word with the Chr., but employed by no other O. T. writer. This particular form (Hithp. Infin. with suffix $3^{\text {rd }}$ plur.) occurs also I Chr. 4, 33; 7, 5. 7. 9. 40; 9, 22; 2 Chr. 31, 16.

מלכוּת. See Driver's list, No. 9.

I For the sake of convenience, I shall often mercly refer to Driver's numbered list, which I have found very complete and accurate. I had nearly finished my own lists before consulting any others.

2 Sixteen, if Ezr. 3,3 is counted. 
8, 3 התיחש לזכרים. Just as in 2 Chr. 3I, I6.

S, I6 ליהליעות. The use of this preposition with the direct object is not uncommon in Chr. Cf. with this verse especially 2 Chr. 17,7 . The resemblance is striking.

מבינים. Cf. I Chr. I 5, 22; 25, 8 (מבין formally contrasted with תלמיר); 27,32, and see notes on Neh. 8, 7 ff. below.

8, I7 נתינים ${ }^{x}$ The word occurs only I Chr. 9, 2 and in numerous passages in Ezra-Neh.; viz. Ezra 2, 43. 58. 70; 7, 7. 24 (Aramaic); 8, I7. 20 (bis); Neh. 3, 26. 31; 7, 46. 60. 73; IO, 29; I I, 3.21 (bis). These passages are all (as I believe) from the hand of the Chronicler.

8, 20 נקבו בשמות. Also I Chr. I2, 3I; I6, 4I; 2 Chr. 28, I5; 31, 19. Only other occurrence, Num. I, I7. A characteristic expression.

8, 2 I רכוש. Also I0, 8. A word that the Chr. is fond of using. I Chr. 27, 3I; 28, I; 2 Chr. 20, 25; 2I, I4. I7; 3I, 3; 32, 29; 35, 7; Ezra I, 4. 6. No other O. T. writer employs it so often.

8, 24 שרי הכהנים. So vs. 29; I0, 5; 2 Chr. 36, 14. These are the only occurrences of this expression.

שנים עשר. Concerning the artificial use of the number I2 in this chapter, cf. Kosters, Wiederherstellung, p. 37. The author of vs. $35 \mathrm{f}$. was the author of the rest of the chapter.

8, 25 ההרימו. See Driver, No. 36. A very singular usage, and occurring only in Chr.

כל ישראל הנמצאים. Cf. 2 Chr. 3I, I; 35, I7. I8; 5, II. A use peculiar to the $\mathrm{Chr}^{2}$

8, 27 בפרי. Only other occurrences of the word, I Chr. 28, I7; Ezra I, Iо.

אדרכנים. Only here and I Chr. 29, 7. A form analogous

I Kethibh נתונים.

2 Cf. however Judg. $20,4 \mathrm{~S}$.

Beihefte z. ZATW. 11. Torrey, The Composition \&o 
to דרכמן (Neh. 7, 7r.\&c.); the one evidently corresponding to Sapeikó two words is worthy of especia! notice, in connection with the other evidence. Cf. Neh. 7, 7 If., and see note there. 8, 30 קבו Mentioned in Driver, l. c., No. I I, among the cliaracteristics of the $\mathrm{Chr}$.

8, על יד מרמות C. Cf. C. על יד יחיאל in the very similar passage I Chr. 29, 7.8.

8, במשקל (so in vs. 26. 30. 33). Cf. I Chr. 28 , I4ff.

8, 35 צפיר Found elsewhere only in two passages from the hand of the Chr.; viz. Ezra 6, 17 (Aramaic); 2 Chr. 29, 2I ' ; and in the-eighth chapter of Daniel.

9, ו וכבלות Cf. 2 Chr. 3I, I. The combination occurs also 2 Chr. 7, I; 29, 29; and once in Daniel.

נבדלל. The only other occurrences in Niphal, aside from Num. 16, 2I, are Ezra 6, 2 I ; I0, 8. I1. I6; I Chr. I2, 8; 23, I3; Neh. 9, 2; I0, 29.

עצי העריצות. An expression often used by the Chr., and by him only; 2 Chr. I3, 9; 32, I 3. I 7 (גו); Ezra 3, 3; 9, 2. I I ; Neh. 9, 30; 10, 29. Cf. also vs. 7; and concerning the Chronicler's habit of combining two plurals, see Zunz, l.c., p. 22.

לכנעני ("namely, the Canaanite", \&c.).2 Such extended use of the preposition $\zeta$ is especially frequent in writings of the Chr. See Giesebrecht, Dic Pracposition Lamed, p. IOI ff.; Driver, No. 39. The passages most nearly parallel to this one are 2 Chr. 2, 12; 23, 4; cf. also I Chr. I3, I; 2 Chr. 28, 15; 33, 8; Ezra 8, 24; Nell. 9, 32.

I Compare both passages with this one, noticing the connection and the wording.

$2 A s$ in Arabic; e. g. Ibn Hishim, ed. Wüstenfeld, p. 435, I 7. 19; 442,3 . 
9, 2 נשיא השה. Also vs. I2; IO, 44; Neh. I 3, 25; I Chr. 23, 22; 2 Chr. II, 2I ; I 3, 21; 24, 3; Ruth I, 4.

עמי הטריצות. See above.

לפ. "A favorite term with Chr." (Driver). See his list, No. 3 .

9, חרד So IO, 3 .

מעל מעל מעל הגולה see note above.

ע. This combination of prepositions is one of the most characteristic marks of the Chr.'s style. See the long and very significant list in Driver (No. 38 ). Even the use of it with an infinitive, which is slightly different, has no parallel in other O. T. writers, except in the phrase עosh. 13, 5; Judg. 3, 3. The use with a substantive, as here (also 3,$13 ; 9,6 ; 10,14$ ), is found only in the Chr. ${ }^{\mathrm{I}}$

9, 5 ואפרשה בפי As in 2 Chr. 6, I2 (I Ki. S, 22). I3.

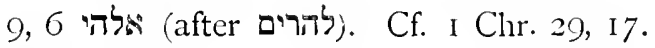

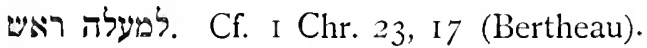

The Chr. is fond of using isy as an adverb, "cxceedingly". That is what we should expect here, and the present construction is very difficult. The conjecture is tempting that רמי originated in a misreading of the first three letters of the following word.

אשמתני. Another uncommon word, used chiefly by the Chr. (I 3 times). Driver, No. I9.

ם2 Ty. Cf. 2 Chr. 28, 9, where the words are used in the same way. See also above, vs. 4.

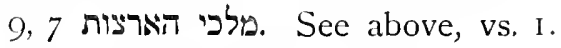

9, II עמי האריצות. Se above.

9, 13 i (also vs. I 5). See above.

I I Ki. I 8,29 cannot be cited to the contrary, for the text there is plainly corrupt (cf. LXX.). 
9, 14 עמי התעבות. Cf. note on vs. I.

לאין שהרית. Cf. I Chr. 22, 4; 2 Chr. I4, I 2; I 5, 3; 20, 5; 2I, I8. Another remarkable use of the preposition. Driver (No. 43) says of it: "Peculiar. Not elsewhere". See also Giesebrecht, Die Praeposition Lamed, p. $92 \mathrm{f}$.

9, I 5 אין לעמוד. Driver, No. 40. Still another syntactical peculiarity.

It appears from the foregoing list that the passages Ezra 7, 27-8, 34; 9, I-I 5 contain a very large proportion of words and expressions found elsewhere only (or in a few cases, chiefly) in the writings of the Chronicler. These expressions are for the most part pretty evenly distributed; yet the way in which they sometimes accumulate in a single verse should be noticed. Take, for example, 7, 28 . The several "ear-marks" noted in this verse are not such as naturally belong together, so that the use of one would stand in any connection with the use of the others. It is therefore purely by accident that they are congregated in this verse, if the Chr. did not write it. It is remarkable that this same accident should happen in a half-dozen other verses in this short portion of narrative; e. g. 8, I. 27; 9, I. 2. 4. 6. I4f. The character of some of the expressions also deserves especial attention. The use of עמי הצרצות and the similar phrases, noted in 9, I. 2.7. II. I4, looks like the habit of a single writer. But this is only one example; if it were alone, it might hardly deserve comment. ${ }^{\mathrm{I}}$ More noticeable still is the peculiar use of the

I It is a fact that speaks volumes, that in the list of "singular syntactical usages" marking the style of the Chronicler, compiled by Driver (Nos. 27-45), all but two (31 and 42; occurring twice and three times, respectively) of the 19 peculiarities named are found likewise in Ezra-Neh., being distributed through all parts of the book except the Aramaic document and the portion written by Nehemiah! 
preposition $ל$; and in particular, of $ל$ ל ל $(9,14) ; \mathrm{h}(7,28)$. Here, if anywhere, we may see one of the most characteristic of those subtle peculiarities that go to make up individual style. This, like the preceding, is a purely syntactical peculiarity, that might appear anywhere in all the extensive post-exilic literature: psalms, narrative, prophecy, apocalypse. But they occur only, and that frequently, in the one book Chr.-Ezra-Neh. Other similar examples might be added.

I will not press the argument of another kind derived from the occurrence of the Greek word אדרכן, Sapetkós

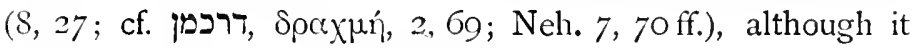
seems to me to be a clear case.

Further, there is nowhere in the sections just examined the slightest indication of the editing or re-writing of an older document. All parts bear one and the same stamp, as critics generally acknowledge; and it is impossible to put the finger on any single verse or collection of verses that will offer reasonable ground for a theory of editorial alteration.

I have passed by the passages 7, I-I I ; 8, 35. 36 without special examination, because it is quite generally acknowledged that they are the work of the Chronicler. They exhibit, however, precisely the same linguistic and stylistic peculiarities as the other portions of the narrative. There is nothing whatever to suggest that they stand on a different footing from the remainder, except that in then the writer lapses into the use of the third person.

The same may be said of ch. IO. The fact might bs easily shown by continuing the preceding table of statistics; but this is unnecessary, for if the Chronicler is proved to have been the author of ch. 7-9, the sane would follow $a$ fortiori of ch. IO. 
The case of Neh. 7, 70- 10,40 is somewhat different, for it has been doubted by some ${ }^{\mathrm{I}}$ whether these chapters proceed from the same hand as Ezra io. I will therefore examine the first clapter of this group in the same way as above, before drawing the final conclusions.

7, 702 fond of this expression.

נתן לצוצוצ. Cf. I Chr. 29, 8; and notice the striking resemblance between the whole passage there (vs. 6-8) and vs. $70-72$ here. Cf. also 2 Chr. 35, $7 \mathrm{ff}$.

זהב .דרכפנים אלך. The same construction in the following verses, also Ezra 2, 69; I Chr. 29, 7.

דרכמנים. Also in the two following verses, and Ezra 2, 69. Evidently the Greek $\delta \rho \alpha x p$. . See note on Ezra S, 27.

7, 7 I רבות (vs. 72 אואר). The parallel passage I Chr. 29, 7 (as well as Ezra 2, 69) uses this uncommon word also.

7,73 השוערים והמשררים. Among the special properties of this writer, who brings them in again and again. They are found only in Chr.-Ezr.-Neh. (Driver, No. 46).

It is an erroneous theory that the status of the "Singers" and "Porters" in Ezr.-Nel. is different from that in Chr.; namely in that the Chr. makes them Levites, while in Ezr.-Neh. they seem to be distinguished fron the Levites. This observation, first made by Graf(?), has been repeated with approval by most recent commentators and critics. 3 The reason for giving the Porters and Singers spccial montion in Ezr.-Neh. is the purpose (the same which moved the Chr. to write this whole listory!) to show that all the institutions of the true "Israel", as they existed in the

I Especially Kuenen. Onderzoek2, p. $509 \mathrm{ff}$.

2 Vs. 69 in Baer.

3 E. g. Smend, Di. Listen, p. 26; Baudissin, Gesch. des A. T. Priesterthums, p. $142 \mathrm{ff}$. 
third century B. C., and as they had been established by Moses and David, were restored complete whon the cxiles returned. In the first place, it is not true that the Chr. does not distinguish: Levites, Singers, Porters, in the same way that they are distinguished in Ezr.-Neh. He states distinctly that they were separate classes, with separate duties; see I Chr. 23, 3-5; and especially ch. 24-26. In 2 Chr. 35, I4. 15 the three classes are enumerated just as in Ezr.-Neh.; and finally, in Neh. 12, 44-47 (generally admitted to be from the hand of the Chr.) the Singers and Porters are twice distinguished from the Levites. Again, it is not true that the Porters and Singers in Ezr.-Neh. are not regarded as Levites. In Neh. I I, I5-I 8 , as also in vs. $22 \mathrm{f}$, the Singers are expressly classed among the Levites. It is perfectly plain, moreover, that in vs. 3 the Singers and Porters are included in the term "Levites". In 12,27 the Levites perform the functions of the Singers; while in 13, IO the Singers do the work of the Levites. Cf. also 7, I. In I3, I I Levites are put in charge of the gates as a part of thcir regular servise (against Baudissin, Gesch. des A. T. Pricsterthums, p. 144); cf. the wording in II, 19; I2, 25.

ונלים. See note on Ezr. 8, I7.

וכל ישראל הנים See below.

ויגע. As in 2 Chr. 5, 3.

$8, I$ I הספר. In this sense (one learned in the Scriptures) I Chr. 27, 32 ; Ezra 7, 6. I ; Neh. 8, 4. 9. I3; 12, 26. 36.

S, הקהל 2 . One of the words most characteristic of the Chr.'s idea of the history as it should have been.

I It is impossible to suppose that these passages in Neh. II were interpolated, or simply adapted (!). And if the ch. is assigned bodily to the Chr., then ch. 7 falls at the same time (see below). 
מבין (also vs. 3). Concerning the Chr.'s fondness for this word, see notes on vs. 7 f. and Ezr. 8, I 6 .

8,4 Concerning the manner of the enumeration here and in vs. 7 , see below.

8, 5 עמדי Cf. 2 Chr. 6, 3 .

8, 6 .ויענו .... As in I Chr. 16, 36, and elsewhere in the Chr.

S, 7 הלוים מבינים את העם (also vs. 9). Just as in 2 Chr. 35,3 ; cf. 30, 32. The use of this expression deserves especial notice. Cf. 2 Chr. I7, 7--9.

על עמדם A characteristic expression. Also 9, 3; I3, I I; 2 Chr. 30, I6; 35, ro; cf. I Chr. 6, 17; 23, 28; 2 Chr. 7, 6; Neh. I2, 44 .

S, שכל ויבינו Both roots are in high favor with the Chr. when he is speaking of "understanding" in the religious sense. For this use of שכ, cf. Ezra 8, IS; I Chr. 26, I4; 22, I2 (שכל ובינה); 2 Chr. 2, I I (שכל ובינה); 30, 22. See also notes on vs. 7. I3.

8, io ל.... The relative omitted. Another striking syntactical peculiarity. See the very significant list in Driver, No. 30.

112. See Driver, No. 6.

תדות. Elsewhere only I Chr. I6, 27; Ezra 6, I6 (Aramaic).

8, i I הלוים.... Cf. vs. 7. 9, and note on the former.

8, I2 שמחה גדולה. A standing expression in the Chr.'s account of such occasions. Cf. vs. I7; also I Chr. 29, 9; 2 Chr. 30, 26; Ezra 3, I2 f.; 6, 22; Neh. I2, 43, \&c.

הבינו. As above.

8, I3 ראשי........ The usual combination. See note on 7,70 .

ולהשכיל. Cf. vs. 8; and for this use of the Hiphil, I Chr. 
28, 19; 2 Chr. 30, 22; Neh. 9, 20. For the peculiar use of the conjunction and preposition, see notes above, and Driver, No. 40.

8, I ויעבירו קול Ezra I, I; Io, 7; 2 Chr. 30, 5; 36, 22. Only other occurrence, Ex. 36, 6 .

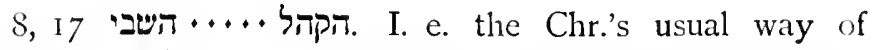
making the גולה and the religious community cocxtensive. Cf. Ezra 6,2 I ; 10,8 (!).

שמחה גדולה See note on vs. I2.

8, is 8 יום ביום Also i Chr. 12, 22; 2 Chr. 8, I3; 24, I I; 30, 21; Ezra 3, 4; 6, 9 (Aramaic). Concerning this and similar expressions in the Chr., see Driver, No. 29 (cf. No. 35).

ויעשי Just as in 2 Chr. 7,9.

Extended comment is unnecessary. We find here the same large proportion of words and expressions characteristic of the Chr. If the two following chapters 9. Io are examined, they will yield the same result. It is to be noticed how, in the lists above presented, these characteristics show themselves in even distribution over all parts of the book-even the Aramaic section Ezra 7, 12-26-excepting only' the Memoirs of Neh. and the Aramaic Document Ezr. 4, 8-6, 14. In these they are almost totally absent (see below).

Kuenen's decision ${ }^{3}$ regarding the style of these chapters (S-IO) in Neh., accepted without question by subsequent writers, has been very widely misleading. He says (after arguing for a comparatively early date of composition): "En daarvóor pleit, dat zij, in weerwil van de overeenkomst met Kron., grammatisch en stylistisch veel hooger staan dan de verhalen, die uit de pen van den Kroniekschrijver zijn

I Onderzoek 2, p. $5 \mathrm{II}$. 
gevloeicl." I think it can be shown that this is a mistake. In the first place, the long Deuteronomic prayer 9, 6-37, by which Kuenen was no doubt influenced, has no right to a place in the discussion; for it is simply a catena of quotations $^{\mathrm{r}}$, not a free composition of the writer. ${ }^{2}$ Concerning the remainder, it will be worth while to give it a brief examination in regard to style.

The passage $7,70-72$, which (as will be shown later) belongs with $7,73-8$, I 8 , not with the preceding list, can be put side by side with the very similar passage I Chr. 29, 6-8.3

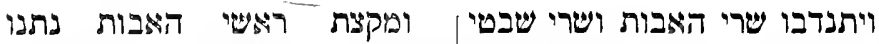

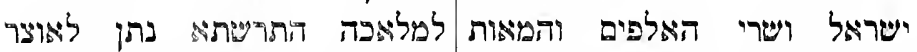

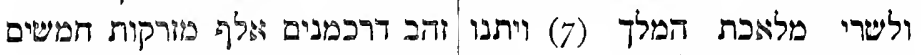

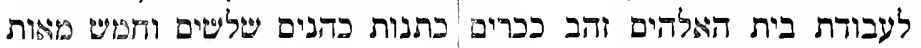

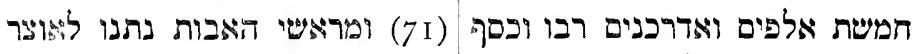

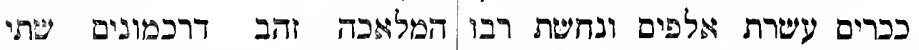

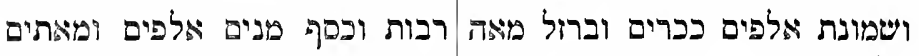

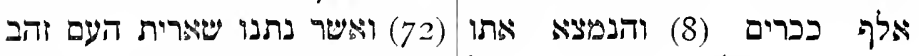

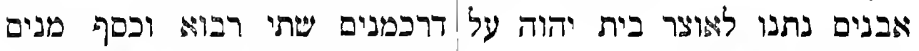

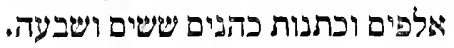

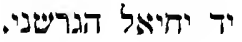

It is certainly not easy to say which of the two passages is the worse written. One thing is plain; they are either by the same hand, or else the one was written in imitation of the other.

In vs. 73 , Wellhausen ${ }^{4}$ wishes to strike out the last three words as unnecessary. But the testimony of text and versions, both here and in the similar passage Ezra

I Cf. De Wette, Fritischer Versuch, 1 So6, p. 181.

2 As so often in Chr. In later times these catenae become still more frequent.

3 Not in Kings.

4 Nachrichten, l. c., p. 177 f. 
3, I, is unanimous in their favor. Moreover, if the Chronicker arote the a'crse, the awkward repetition is sufficiently explained; it is just what we should expect from him. Cf. I Chr. 5, 24; 28, 2 I ; Ezra S, 35, \&c. Those who find it hard to believe that the confusion in the first half of the verse is due to the original writer need only compare I Chr. 9, 2; 12, 40; 29, I.

In 8,2 , the manner of introducing the parenthetical clauses is a good example of the Chr.'s slovenly style; the impossible וכל מבין לשמע (vs. Inבינים 3), in particular, is worthy of that writer.

Vs. 8 is a specimen of such Hebrew as only the Chr. can write or understand. Vs. 7 and 13 are as good examples of his most glaring faults of style as can be found anywhere. The clunsy way of using the proper names in 0, 4 f. is very characteristic; cf. S, 7; Ezra 2, 2; I Chr. $\mathrm{I} 6,4 \mathrm{ff}$, \& $\& \mathrm{c}$.

In ch. IO, the first verse shows us the Chr. at his worst. It is hard to see how any part of it could be more awkwardly expressed. ${ }^{2}$ Vs. 2-28 is a list of names. The rest of the chapter, vs. 29-40, belongs in the same class with vs. I. To speak more particularly: in vs. $29 \mathrm{f}$. there is the labored accumulation of substantives and clauses, in vs. 32 the awkward suspended construction, to be found on every page written by the Chr. Is there any Hebrew style worse than that exhibited in vs. 34 f.? Such matters as logical and grammatical connection were evidently of

I Cf. Io, 29.

2 It is certain, at all events, that it is narration, belonging with the following, not with the preceding. Ryle, Commentary, p. 266, says: "The view that the verse resumes the narrative of $9, \mathrm{I}-5$ is very improbable on account of the use of the $I^{\text {st }}$ person plur., which has not been employed in this section." But how about $10,31 \mathrm{ff}$.-almost the very next verses of narrative?! 
no concern to this writer. The same may be said of vs. $3 \mathrm{~S}$ and 40 .

In conclusion: it might be possible, it would not be easy, to find a portion of Chr. of equal extent written more abominably than Nell. 7, 70-9, 5; 10, 1-40.

If there is any such thing as a valid argument from language, style, and recurrence of characteristic ideas, we have an example of the kind before us. If the books in question stood in no sort of external connection with one another in the O.T., the proof would even then be well nigh conclusive; but when it is borne in mind that the author of the book of Chronicles is acknowledged to have written a considerable part of Ezra-Nehemiah-in fact, all of the Hebrew narrative up to this point,-there is simply nothing more to be said.

It remains to notice the explanation (now hardly necessary) of that which has long been a chief obstacle to the rigint understanding of the narrative in these books; namely, the repeated and bewildering change from third person to first, and back again; as at Ezra 7, 27; 8, $35 \mathrm{f}$.; 9, I; IO, I; Neh. IO, I. 29. 3I ; also Neh. I2, 3I. 43; I3, 4. It is the confusion raised by a writer who is narrating somebody else's personal recollections, on the sole basis of his own imagination, and doing it carelessly. Now he gives his hero the word, now tells the story himself. That which caused the Chronicler to fall into this unfortunate method was Nehemiah's own "Memoir", written throughout in the first person. Wellhausen, Israelitische and jüdische Geschichte2, p. I69, note, says: "Der Gedanke, Memoiren zu schreiben, ist in jener Zeit durchaus neu; unmöglich können zwei Männer selbständig und unabhängig darauf verfallen scin. Vielmehr ist Nehemia dem Beispiel Ezras gefolgt und hat dessen Memoiren seine eigenen zur Seite 
gestellt", \&c. What Wellhausen supposes Nehemiah to have done for himself, the Chronicler actually did, or tried to do, for his hero, Ezra. As he was not trying to "forge" documents, as we understand the term (such an idea could certainly never have occurred to him), it was a matter of no concern to him that the illusion was not always kept up, but the phantom Ezra sometimes disappeared altogether.

The historical probability, or improbability, of the Ezra story will receive brief notice further on. For the present it may be said, that so far as the literary form is concerned, there is nothing in the "Ezra Memoirs" to justify the supposition that the Chronicler used a written source, or written sources, in compiling them.

\section{The Original Fosition of Neh. 7, $70^{\mathrm{I}}-8,18 ; 9.10$.}

The three chapters Neh. 8-IO are out of place where they now stand. Ch. I I forms the proper continuation of ch. 7 , as critics generally agree. Moreover, the intervening chapters belong, not to Nehemiah's narrative, but to that concerning Ezra and his work. They are evidently of one piece with the story told in Ezra 7-IO; just how they are related to it has remained an unsolved problem. Manifestly, Nel. $\&$ cannot be the sequel of Ezra IO, as in I Esdras. Nor does Kosters' use of axe and crowbar yield satisfactory results. I believe it is possible to determine, beyond any reasonable doubt, I. where these chapters originally stood; and 2. how they came into their present connection.

The best starting-point is found in the verses $7,70-73^{2}$, where there is an allusion of a very definite character. "And

I Vs. 69 in Baer.

$2 \mathrm{Vs} .69-72$ in Baer. 
some of the chief of the fathers gave to the treasure of the work, \&c." The gifts include not only gold and silver in large amounts, but also bowls for use in the temple, and a good many priests' garments. What was the nature of "the work" that required such gifts as these? Certainly not the building of the city walls, nor any other work mentioned or suggested in this part of Nehemiah. The reference must be to the restoring or carrying on of the Timpli scrvice ${ }^{\mathrm{x}}$. (Cf. not only the parallel passage Ezra 2, $68 \mathrm{f}$., but also I Chr. 29, 6-S.) But how is it possible to explain the sudden, indirect allusion to the Temple service, in this place where it would be meaningless? The manifest and only satisfactory solution of the difficulty is that the misplaced section of the Ezra document begins, not with Neh. 8, I, or $7,73 \mathrm{~b}^{2}$, but with 7,70 . The hypothesis, adopted by most modern critics, that these four concluding verses of ch. 7 were copied, in connection with the preceding list, from an older document, is as unnecessary as it is improbable. ${ }^{3}$

It remains to ask where in the Ezra narrative thesc statements regarding gifts for the Temple worship would be in their proper place. The question is easily answered; there is only one place, namely, at the end of Ezra $S$. There, they would be just what is needed; they form, moreover, as natural a continuation of the close of that chapter as could be desired. The narrator (the Chronicler)

I So also Kosters, Wiederherstelluin, 1) 35; though he fails to draw the necessary conclusion, that the verses are not in their original connection.

2 Schrader, Smend, Ryssel, Kuenen, Stade, Cornill, Driver, König, Ryle, Kosters, al.

3 On the other hand, it would evidently be an untenable hypothesis that these verses were borrowed and adapted from Ezra 2 by a later scribe or editor. 
has told of the arrival at Jerusalem of the Ezra expedition, with the gifts from Babylon for the temple. The king's governors in the province, also, help with gifts (sives, cf. Ezra I, 4) the work of the house of $\operatorname{God}(8,36 \mathrm{~b})$. Then followed the verses Neh. 7, $70 \mathrm{ff}$., telling how some of the chief of the fathers and of the rest of the people gave to the work; and finally, how the members of this expedition settled down in their respective places-a statement that is noticeably absent at the end of Ezra $S$ as it now stands. ${ }^{\mathrm{T}}$

Next came the account of the reading of the Law, Neh. $\$$. This was a principal object of Ezra's journey; he was "an expert in the law of Moses" (Ezra 7,6), and set out for Jerusalem with the express purpose of teaching and applying it there (vs. IO). In the letter of Artaxerxes, the king is represented as taking this same view of Ezra's mission (vs. I4; cf. vs. I2. 2 I. 25 f.). It is then most natural that the narrator should tell, first of all, how Ezra set about accomplishing his purpose. According to the restored order of the chapters, the reading of the Law was his first official act after reaching Jerusalem-as soon as the sacred "seventh month" was come.

But when the end of Neh. $S$ is reached, a new difficulty arises. Chapters 9. Io cannot have formed the original sequel. The sudden transition from feasting to sackcloth and ashes, without any statement of the reason why, is at least very noticeable; and there are other difficulties in the way. Kosters ${ }^{2}$ finds the opening verses of chap. 9 well nigh incomprehensible as they stand; the impression gained from them is that the convening of the assembly was occasioned, not by the reading of the law, but by the separation of Israel from foreigners. In his attempt to determine the

I Notice also verses $32 \mathrm{f}$.

2 Wiederherstellung, P. 6f ff. 
original order of the narrative, he feels obliged to put ch. 8 after ch. 9. 10.' Wellhausen, in his reply ${ }^{2}$, fails to dispose of all the difficulties; he has, moreover, in another place, himself called attention to the chief one of them. ${ }^{3}$

It has been generally taken for granted that the mourning and fasting of 9, If. was occasioned by the reading of the Law. The people were in distress because they had not known, and therefore had not kept, all these commandments. But this is nowhere stated, in either of the two chapters 9. IO, nor is it the most natural way of interpreting them, when they are taken by themselves. The true state of the case may be surmised from the hint given in $9,2 \mathrm{a}$, and repeated later (especially 10, 29): "And the sced of Isracl separated themselves from all strangers" (cf. Ezra IO, II; 9, If.). In the penitent assembly and solemn covenant of Neh. 9. 10 we have the original conclusion of Ezra 9. IO. All commentators remark that Ezra Io ends in a most unsatisfactory way. Even when the text of verse 44 is restored in accordance with I Esdras ${ }^{4}$, it seems certain that the story of "the seed of Israel" and their heathen marriages could not have ended at this point. Neh. 9. 10 gives precisely the continuation that is needed. After Ezra's extreme measures have been carried through, and the heathen wives are formally dismissed, then comes the second part of the reform, which is hardly less important than the first. The children of Israel come together, humbled and penitent, in solemn assembly; and enter into

I L. c., p. $S_{5} \mathrm{f}$.

2 Nachrichten, p. $173 \mathrm{f}$.

3 Israel. u. jüt. Geschichte 1, p. 135, note 2: "Wunderlich an seiner Stelle ist der erste Satz von Neh. 9, 2."

4 See e. $g$. the attempts in Oet1li, Comm., p. I75; van Hoonacker, Néhémie, p. 37. (Kosters, p. I02, dismisses Oettli's emendation as im. possible because of the masc. suffix; but see Ezr. I0, 3.) 
a formal covenant I (written and signed, and sealed by "a curse and an oath", IO, 30), the first clause of which is "that we would not give our daughters unto the people of the land, nor take their daughters for our sons" (vs. 3I; notice also the wording of vs. $29 \mathrm{f}$.). There follow other specifications, most of then easily recognized as belonging to the pet interests of the Chronicler - provision for tithes, and all sorts of offerings for the temple service, and especially the gifts for the Levites; so that the covenant is finally made to include pretty much all virtue as seen from his peculiar standpoint. The story of Ezra is thus brought to a fitting close.

It may be remarked here that the dates given from time to time in Ezra 7-IO; Neh. S-IO now follow one another in perfect order, each event falling into its proper place. Ezra begins his journey, at Babylon, in the seventh year of Artaxerxes, on the first day of the first month (7, 9; cf. 8 , I5. 3I). His company arrives at Jerusalem on the first day of the fifth month $(7,8.9)$; and there they all remain for a few days $(8,32 \mathrm{f}$.), before dispersing to "their" cities and villages (Neh. 7, 73). On the first day of the seventh month $(8,1.2)$ all assemble at Jerusalem to hear the Law read. The reading is continued on the second day (vs. I3). The Feast of Tabernacles is observed at the usual time, from the fifteenth to the twenty-second day of the month (verse I8). Soon after this (Ezra 9, I), Ezra hears of the obnoxious marriages, and measures are taken to remove the evil. After three days of preparation (IO, 8.9), the people are all assembled in Jerusalem on the twentieth day of the ninth month (vs. 9). On the first day of the tenth month (vs. I6) Ezra and his associates begin their work,

I Cf. Ezr. 10, 3-5.

Beihefte z. ZATW. 11. Turrey, The Composition \&c. 
and bring it to an end on the first day of the first month (vs. 17). This is apparently the beginning of the eighth year of Artaxerxes. On the twenty-fourth day of this month (Neh. 9, I) the people assemble once more, for the purpose of taking the covenant.

It has thus been shown that the original order of chapters in the story of Ezra was the following: Ezra 7. S; Neh. 7, 70-8, I8; Ezra 9. I0; Neh. 9. I0. Whoever admits that these chapters in the book of Nehemiah belonged originally in the Ezra narrative, will hardly dissent from the above conclusion after having once tested it.

As to the way-in which the three chapters Neh. S- IO came to be misplaced, the following is at least a plausible hypothesis. The transposition was due to the close resemblance of the passage Neh. 7, 70-8, I to Ezra 2, 68-3, I. ${ }^{x}$ Neh. $7,70-8$, is thus came to be removed to the place directly after the list 7, 6-69 (=Ezra 2, $1-67)$, where it was supposed to belong. Once there, it would not easily be removed.

But this first transposition made a second absolutely necessary. The two chapters Neh. 9. Io plainly presupposc the public reading of the Law, as narrated in Neh. 8 , and cannot possibly precede it; see especially 9, 3; IO, 29. 30. 35. 37. They were therefore placed after it.

But the tradition was not lost, that these incidents $b c$ longed to the history of Eara. Hence the attempt, represented by I Esdras, to restore the chapters to their proper place. The section thus transferred to the end of the book of Ezra began with Neh. 7, 73, the only place where it could have begun.

I Such a repetition is not at all surprising under the circumstances - the two similar expeditions from Babylonia. And it might well lead a copyist astray. 


\section{The Chronicler's Share in Nch. $I-7$.}

With Neh. I it is evident that a new writer appears, whose work can be recognized in the greater part of the first six chapters of the book. The narrative is quite different in style and tone from all that has preceded, and its peculiarities of expression are not those of the Chr., such as appear everywhere in the chapters hitherto discussed. Hardly a single one of all the words and phrases brought together in the foregoing lists is to be found here ${ }^{\mathrm{x}}$, cxcopt in chaptor $3,1-32$, which will be considered by itself.

This is very significant, as showing (if any further demonstration of the fact were needed) that the peculiarities mentioned are not those of a period of literature, but of an individual writer. ${ }^{2}$ It will be seen that when ch. I I-13 is reached they begin again to be scattered in as profusely as ever. There are other more positive indications. The date at the beginning of the first ch. could not have been written in this way (simply "in the twentieth year") by the Chr. The inhabitants of Jerusalem and the vicinity are called "the Jews" (היהודים); never the גולה

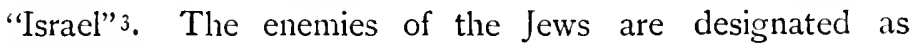

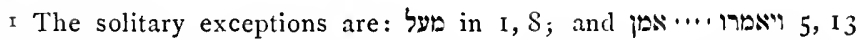
(in a clause interpolated by the Chr.). In the long list compiled by Driver, these first chapters of Neh. do not appear (except in the case of להרבה and), though each of the other chapters is frequently represented.

2 Of course it is to be expected that the Chr., who is editing the writings of Neh., should be occasionally found imitating him, in the part of the book composed by himself. Thus 2, 8 (last clause), also Ezra 7, 6. 9. 28; cf. Nel. 2, is. Neh.'s self-satisficd prayer, 5, 19, is repeated for him by the Chr. 13, 14. 22. 31 .

3 It is worthy of notice that the term which is constantly used by Neh. and in the Aramaic document in Ezra, seems to he avoided by the Chr. See note on Neh. I3, 23 . 
Moabites, Ammonites, Arabians and Ashdodites (never mentioned as enemies in Chr.), rather than by the use of the convenient and non-committal עמי ההריצות. The Levites, Singers, \&c. disappear entirely, and even the priests hardly receive mention.

Examination of the narrative seems to show that the Chr. has followed his usual labor-saving method; giving his source entire, so far as possible, and adding from time to time his own interpolations.

Ch. I he seems to have left untouched. In ch. 2, vs. 7-9a was probably inserted by him. Tחוות עבר הנהר, These, not mentioned elsewhere by Nel., play a similar part once and again in Ezra. The reason for introducing the mention of these official letters here is apparent from Ezra 5, 3. 6; 6, 6ff.; I Esdr. 4, 47 ; Ezra 7, 21 ; 8, 36. For the commandment concerning wood from the king's forest, cf. 2 Chr. $2,2$. 7, \&c.; I Esdr. 4, 48; Ezra 3, \%. The verb קרז (Pi el) occurs elsewhere only 2 Chr. 34, I I Neh. 3, I. 3.6 (all written by the Chr., as I shall endeavor to show) ${ }^{\mathrm{I}}$; Ps I04, 3. The expression הבירה השר לבית seems to bring us down at once into the last centuries B. C. It can only mean here the fortified court or enclosure of the temple; as occasionally in the Talmud. With this use of the word בירה belongs that according to which the temple itsclf was thus called; as in I Chr. 29, I. 19, and apparently in Neh. 7, 2. So also in the Talmud. See Jer. Pesachim VII. 35a; B. Zebachim I04b; in both of which passages these two uses of the term are put side by side, and the passage in I Chr. is cited. ${ }^{2}$ See

I In Nel. 3, 1 read קרשוהו (twice). The emendation is rendered certain by the comparison of vs. 3. 6; notice also the LXX i|riaoar ( $=$ קדithout the suffix).

2 It is not surprising that in some Greek Mss. (not "the Septuagint", Wellhausen, Gesch.2, p. 166) the mention of this בירה in the present passage should be omitted altogether. 
note on 7,2 , below, where the evidence of the Chr.'s presence is equally strong. With the mention of the "gates" of this enclosure, cf. I Chr. 9, I7-27 (especially vs. 23); 26 , I $2 \mathrm{ff}$. Still another, and a very weighty, reason for supposing the interpolation is found in the clause $9 b$, which is the proper sequel of vs. 6 , but is quite out of place after $9 \mathrm{a}^{\mathrm{r}}$.

With $3, \mathrm{I}-32$ we are again in the domain of the Chr. The mere fact of a new list of names is sufficient to arouse suspicion, when it is borne in mind that we are dealing with a writer who had lists on the brain. Here is certainly a good place for another of the inevitable catalogues. And all the indications point in this direction. First of all, though there is very little opportunity here for the appearance of words and expressions characteristic of the Chr., yet some of these do appear, hardly by accident. The Levites and Nethinim, too, are given just the prominence that might be expected in any statistics compiled by him. It may also be remarked that the high priest, who here apparently leads the work, is not mentioned elsewhere by Neh. in these first six chapters, though there is no lack of opportunity for doing so. ${ }^{2}$ Among the expressions that suggest the Chr., the following may be especially noted:

3, I ויקם . C.... Cf. Ezra 3, 2.

הכהנים. These must of course be the leaders, whenever the Chr. is writing the history. So also we have the Levites in vs. 17, and the Nethinim in 26. 31 .

I To avoid the difficulty by translating pluperfect, is to ignore Hebrew syntax.

2 As for the names of the various gates, towers, buildings, and other features of the city mentioned in this chapter (most of them also ch. 12), they undoubtedly give us a description of the Jerusalem of the Chr.'s own time. 
קדשמהזי (bis). Read in both cases (see note on 2,8), and cf. vs. 3. 6; 2 Chr. 34, I I. ${ }^{\mathrm{T}}$

3, 2 על ידו Also in the verses following: 4 (ter). 5.7. S (bis). 9. IO (bis). I2. I7. 19. Used in precisely the same way 2 Chr. I7, I5. I6. I8. Cf. also Neh. I3, I3; I Chr. 7, 29; 2 Clir. 21, 16; 3I, 15. The only other passage in the O. T. that can be compared is Jos. $15,46$.

3, 5 מדירית. Thus absolutely 2 Chr. 23, 20; Nel. IO, 30.

עבועy. In the signification "Dienstpflicht"; cf. I Chr. 26, 30 (Gramberg, Dic Chronik, is23, p. 8).

3, 8 a a similarly vs. 3If. Cf. I Chr. 4, 21.22 .23$.

3, I I תים (also vs. 19. 20. 21. 24. 27. 30). Cf. I2, 38 .

3, I6 שר חצי פלי (cf. vs. 9. I2. 14. I5. I8). Cf. I Chr. 2, 50 ff.; especially 52. 54.

3, 26 ה. Also vs. 3I. See note on Ezra 8, I7.

3, 30 rawd. For לשפת. Only here and 12, 44; 13, 7. See note on the latter passage.

It can hardly be doubted, in view of all this, that for $3,1-32$ we are indebted to the same hand that compiled all the other lists in the book.

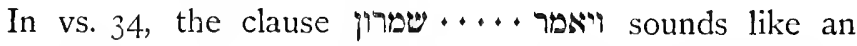
interpolation; not so much because of the double רמי" as because of the mention of Samaria. Neh. always calls Sanballat "the Horonite"; the prince of a stronghold near by Jerusalem, but nowhere near Samaria. The latter city he never mentions, nor does it anywhere appear that he knew of Samaritan enemies.

I The verb pis used of persons or things (temple, altar, \&c.) which are made "holy" for the cultus. To speak of "sanctifying" such a thing as a gate or a wall is unheard of. The "parallel" (1 Ki. 8, 64) adduced by bertheau-Kyssel, Oettli, Ryle, and others, has no resemblance to the present instance. 
Ch. 4 appears to be intact. ${ }^{x}$ In ch. 5, the first clause of vs. I 3 b, יויאמרו י..., is a Chr. addition. Notice the use of phe, and cf. I Chr. I6, 36; Neh. S, 6.

With ch. 7 , the uninterrupted reign of the Chr. begins again. As the long catalogue containing the names of "those that returned .... with Zerubbabel, Jeshua," and the rest (vs. 6-69) is an important factor in the analysis of the book, and as the decision as to its probable origin must precede the discussion of vs. $\mathrm{I}-5$, it will be well to examine it first. I have already (in speaking of Ezra $\mathrm{I}-6$ ) stated my opinion as to the source of this catalogue; the argument was reserved for this place.

I. Both structure and contents suggest the Chr. The lists of names, which he is perpetually inventing or reconstructing in order to enrich his history, in season and out of season, often show their origin plainly. The one before us is made up, half of names of men, half of names of places. The Chr.'s fondness for locating the members of the congregation in "their cities" is characteristic. ${ }^{2}$ In a number of his catalogues he concludes with a formidable list of cities and villages. Thus the latter half of Neh. I I; I Chr. 4. 6; cf. also 26, I 3 ff. His especial interest in Levites, Singers and Porters has already received frequent comment. Their presence here is noticeable in itself, and will be still more so when we compare the lists in I Chr. 9. I 5 (!). 23-26(!); Ezra IO; Neh. I I. I2, all constructed after the same model; to say nothing of the many single verses such as 2 Chr. 34, I2 f.; 35, I 5 ; Ezra 7, 7. 24; Neh. 10, 29; 12, 47.

2. The style of the narrative portions of the section is

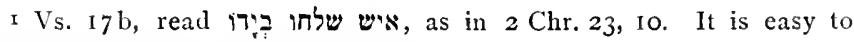
sec how 17 might be mistaken for $\square$.

2 Cf. also such passages as I Chr. 2, 50 f. 52 ff. (!); 4, 14, \&c. 
like that in Chr. It is only necessary to call attention to vs. 6. 7. 61. 64. ${ }^{\mathrm{I}}$ It may be also worth noticing that the manner of writing compound numerals (the hundreds first) in this list and in Neh. I I is that invariably adopted by the $\mathrm{Chr}^{2}$

3. There is also the evidence furnished by a good many single words and expressions.

7,6 אלה בעי המדינה. Cf. Neh. II, 3; and the Chr.'s favorite בני העולי העודה.

העלים משבי הגולה. Cf. Ezra 3, 8; 6, 2I ; 8, 35; Neh. 8, I7. אישי לעירו The Chr.'s idée fixe!

7, 7. The intrnduction of these twelve leaders certainly does not inspire confidence in the trustworthiness of the document. Cf. Kosters, Wiederhorstellung, p. $36 \mathrm{ff} .^{3}$

7, בגי עבדי שלמה Also vs. 60; I I, 3. Not only the Porters, Singers, and Nethinim, but also this subdivision of the last-named class, must be connected in direct line, through the exiles in Babylon, with the institutions of David and Solomon. Cf. Ezra \$, 20 (Bertheau). According to the Chr., no portion or institution of the true Israel ceased in the exile, or originated after it.

7, 61 בית אבותם. One of the expressions that the Chr. delights to use.

7, 63 מבני ומן דכהנים, Ezra 2, with which cf. IO, I8; Neh. 1 2, 35; I Chr. 9, 30; בני הלוים, I Chr. 1 5, 15; 24, 30; בני המשררים, Neh. I2, 28; בני הקהתים, 2 Chr. 20, I9; 34, 12. These expressions do not occur elsewhere.

7, 64 מתיחשים. See note on Ezra 8, I.

1 For the awkward way of enumerating in vs. 7.61 (in the parallel Ezra 2, 59 and in the LXX here, there is no conjunc. before the name (אמא), cf. I Chr. 4, 24; 26, 23 ; Neh. 12, 8. 25. 36. 41.

2 See the tables in König, Lehrgebäude, II. p. 217-220.

3 Kosters' conclusion is, that this verse was interpolated by the Clir. 
ויגאלו מן הבהנה. Cf. 13, 29, and see note there. The coincidence is remarkable; the more so, as it evidently cannot be a case of borrowing; the uncommon root גול is not used in the same way in the two passages.

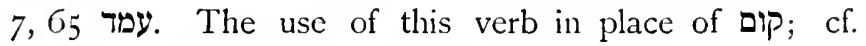
Gramberg, Dic Chronik, p. 43; Zunz, p. 25; \&c.

7, 66 באחד. "Together." So 2 Chr. 5, 13; Ezra 3, 9; 6, 20. Elsewhere, Is. 65, 25; Eccl. I I, 6.

רבואי Cf. vs. 7I f.; Ezra 2, 69; I Chr. 29, 7.

It seems plain, therefore, that we have here (and in ch. II, which is the immediate and necessary sequel) ${ }^{\mathrm{I}}$ tables compiled by the Chr., according to his usual purpose and method, with the aim of giving the exact statistical basis of the restored community at the time when everything was once more in running order.

As for vs. I -5 , the most hasty examination shows that at least some portions were written by the Chr. Vs. Ib could have been written by no one else; 3 b suggests him with almost every word; vs. 4 expresses just his idea of the city at that time (contrast the last clause with Hag. I, 4!), and furnishes the necessary introduction to the following list; vs. 5 is certainly all his property. The question remains, whether some naterial from the Neh. document may not be incorporated here, especially in vs.2.3. This appears plausible at first, but closer examination secms to prove the contrary.

The significance of all these specifications in vs. $\mathrm{I}-3$ concerning the doors, the appointment of gate-keepers, the regulations for the time and manner of opening and closing the gates, the establishment of the "watches", becomes

x The verses 7, 70-73 (Baer, 69-72) have nothing to do with the preceding, but belong with ch. 8 , as we have already seen. 
apparent upon comparing I Chr. 9, I7-27; 26, 12-19; and such descriptions of the Jerusalem police service as that given in Schürer, Gesch., II. p. 217--220. According to the Chr., to whom such things were an every-day matter, all this service had been a feature of the true Israel from the beginning, and was restored by Neh. just as soon as the city walls and the wall of the temple enclosure (הבירה

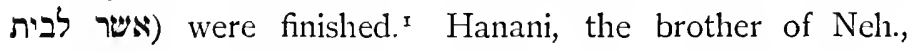
had been mentioned in I, 2; it was easy to introduce him again. It is the mention of his companion Hananiah, the שר הבירה , that deserves especial notice. I have already spoken (note on 2,8 ) of the peculiar use of בירה as a designation of the temple, with its courts, found in the Rabbinic writings and in Chr. In the case before us we have a striking example of this usage, stamping the present passage as belonging in the same class with I Chr. 29. The

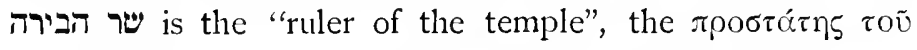
iepoũ, 2 Macc. 3, 4; cf. Jos. Antt. XX, 6, 2, \&c. ${ }^{2}$. The designation is in common use in the Talmud. ${ }^{3}$ It can hardly be doubted, in view of all this, that $7, \mathrm{I}-5$ is the work of the Chr. alone.

\section{E. The Origin of $\mathrm{Ne}^{2} \mathrm{II}-\mathrm{I3}$.}

Chapters II and 12 may be dismissed with a very few words. The former is the necessary continuation of $7,5-69$;

I The conjecture may be ventured that the word שער originally stood before רלושים, in vs. 2 (cf. vs. 3). This would be a decided improvement on the present text. Mention is made in the Talmud of the officer in charge of the gate-service (על נעילת שערים); see Schürer, loc. cit.

2 Cf. also נגיר בית האלהים, I Chr. 9, 11; 2 Chr. 31, I3.

3 See Derenbourg, Histoire de la Palestine, p. 48; Schürer, Gesch., II. p. 219; Grimm, Zueites Buch der Maccabiater, p. $66 \mathrm{f}$; and the citations in Levy. 
in fact, without this as the immodiate sequel the list in ch. 7 could be of no possible use where it stands. ${ }^{I}$ The purpose of the compilation of these lists is apparent only on the supposition that the Chr. was the compiler. Ifis motive is plain enough; it is the same that dominates all his post-exilic history. From internal indications, also (nature and structure of the catalogues; wording and style), the origin of ch. I I cannot for a moment be in doubt.

With ch. I2 the case is quite as simple. Every word of it was written by the Chr. It is generally admitted that he was the author of vs. I-26;44-47. Concerning the rest of the chapter there is difference of opinion-caused chiefly by the Chr.'s unfortunate habit (already referred to) of occasionally letting his heroes speak for themselves. ${ }^{2}$ The prevailing theory has been that Neh. wrote the whole of vs. 27-43. Ryssel, in Kautzsch's Dic heilige Schrift d's A. T., divides this section as follows: to the Chr. belong $27-30.33-36$. $4 \mathrm{I}-43$; to Nehemiah, 3 I f.. 37-40; that is, wherever the "Ichstuicke" can be escaped, the writer is the Chr.! It would be difficult, if not impossible, to formulate a reasonable theory according to which the Chr. should have incorporated these small fragments of Neh.'s narrative, and no more. The fact is, there is nothing in this story of the dedication of the walls that deserves to be talien seriously. The necessity of such a ceremony would of course be keenly felt by the $\mathrm{Chr} .^{3}$; it is not so likely that

I Kosters (op. cit., p. 31) finds 7,5-69 so foreign to its present context that he feels compelled to use violence. The list is accordingly beheaded, and put, with ch. 8 , at the end of the book.

2 As vs. 27-43 continues the narrative of ch. $1-6$ (where Neh. was always the speaker), it is most natural that the Chr. should here (vs. $31.3^{\&} .40$ ) give him the word again.

3 Cf. 1 Chr. $15,3-25 ; 2$ Chr. 5, 2-14; 7, 4-10; 29, 25-30; Ezra $3,10-13 ; 6,16-22$. 
it would have occurred to Neh. The manner of this solemn procession, in all its details, is familiar to readers of the Chronicler; and the narrative exhibits at every point the marks that indicate his work. ${ }^{\mathrm{x}}$

Ch. I 3 will need more careful examination. Most recent critics have followed Kuenen (Onderzoek ${ }^{2}$, i887, p. 447, $499 \mathrm{f} ., 5 \mathrm{I} 3)$ in regarding vs. $\mathrm{I}-3$ as the continuation of I2, 44-47, and assigning them to the $\mathrm{Chr}^{2}$, leaving the rest of the chapter as the untouched work of Neh. The one potent reason for making the division here is the fact that, while vs. I-3 manifestly comes from a time later than Neh., the anecdote introduced by vs. 4 is zoritten in the first person, and must therefore be entitled to a place in the "Memoirs" without further examination. The evidence now presented will, I think, lead to a different conclusion.

I3, ולפני מזה ל. Bertheau-Ryssel (p. 346): "Verfehit ist es, לפני מוה auf die vorher berichtete Absonderung des ערב von Israel v. 3 beziehen zu wollen." But a better continuation could not be wished for. And for what other purpose were those verses written than to introduce this very anecdote? To suppose, with Bertheau-Ryssel, that the words refer to a lost portion of Neh.'s narrative, in which he tells how he returned to Babylon and then came again to Jerusalem, is to shut the eyes to what is obvious, and moreover, to get into trouble at once (see below).

אלישיב הכהן. The Jewish priesthood of the time of Alexander the Great was not all that it should have been,

I Driver, Introd., p. 511 , says: "The phraseology of the Chr. is especially noticeable in Ezra 1. 3. 6, 16-22. 7, 1-10. Neh. 12, 22-26. 43-47." The inaccuracy of this statement is again strikingly manifest in these last chapters of Nell. In what respect is the phraseology of the Chr. more apparent in Ezra 3. 6, 16-22 than in Neh. I2, 27-43; or in Neh. 12, 43-47 than in $13,4-13$ ?

2 Thus Cornill, Ryssel, Oettli, Ryle, al. 
as we know. The events of the Chr.'s own generation, combined with Neh. 6, I7 ff., \&c. might well have furnished him with the material for this episode of the high priest. Cf. also vs. 28. Eliashib is mentioned Ezra I0, 6. 24. 27. 36; Neh. 3, I. 20. 21; I2, 10. 22. 23; I 3, 7. 2S; all passages written by the Chr. Neh. does not give the name of any pricst. The only mention of priests by him is at 2,16 ; 5, 12. Levites are not mentioned at all.

לשכת בית הלהינו. Cf. IO, 38 ff. (same words); I2, 44; Ezra 8, 29; I Chr. 9, 33; 2 Chr. 3I, I Iff. (not in Kings). See also vs. 7 , and note.

I3, ושם היו נתנים וגו' Cf. IO, 3S-4O; I2, 44. It is plain that vs. 5, and therefore the aihole passage 4-y, was written by the Chr.

מצות. A peculiar use. Cf. I0, 33.

המשררים והשוערים. These are dragged in once more.

I3, 6 בשנת וגור Cf. 5, I4. This would require us to suppose that Neh. wrote and finished his account of the building of the city wall at the end of his term of service as governor, and then added ch. I 3 as a sort of appendix after coming to Jerusalem the second time. The case is much simpler, however. The Chr., wishing to represent "all this" as having happened during Neh.'s absence, made use of the date given in 5, I4. Notice here, in contrast with המלך there. It does not seem to have occurred to Bertheau (Ryssel) that if his theory is correct, vs. 6.7 a (at least) must be an explanatory note by a later hand-written in the first person, nevertheless!

I3, וציאבינה ברעה Cf. Ezra 8, I5.

נשכה. This form (for לשכה) elsewhere only 3, 30; I2, 44. Cf. especially the latter passage.

I3, IO מניות הלוים. Cf. I2, 44. 47 (the only other occurrences of this plural in the $O$ T.) 2 Chr. $3 \mathrm{I}, 4$. 
מצו לשדהו. Cf. 2 Chr. 3I, I9; Neh. I2, 44. The remainder of the verse betrays its authorship beyond a doubt.

13, II ואעמדם על עמדם. Another unmistakable ear-mark. See note on Neh. 8, 7 .

I3, I מעשר וגו' Cf. vs. 5, and see note there.

I3, I3. The style of this verse marks it sufficiently as belonging to the Chr., even without "the Levites" and the usual enumeration of temple officials.

ניאמנים. Cf. 7, 2; and especially, 2 Chr. 19, 9; 31, I2.

I3, I4 זכרה ל. Neh.'s fondness for these interjected prayers is quite noticeable $(3,36 \mathrm{f}$; 5, 19; 6, I4). Such peculiarities as this would be most readily seized upon by an imitator. The Chr. introduces this formula not only here, but also vs. 22. 29. $3 \mathrm{I}$.

Tor. Cf. 2 Chr. 6, 42; 32, 32; 35, 26. These are the only examples in the O. T. of the use of aיח for "good works."

\section{I3, I 5 בימים ההמה. Cf. I2, 44; I3, I.}

בשבתת. Cf. 9, 14; 10, 32. It is noticeable that the covenant in which the Ezra story culminates (Neh. IO, 30-40) corresponds throughout to this closing chapter of Neh., both in the matter included and often in the verbal form: marriage with foreigners, IO, 3 I ; I3, 23-27; trading on the Sabbath, IO, 32; I3 I 5-22; offerings for the temple service, and for the priests and Levites, IO, 33-40; I2, 44-I3, I4.

I3, I6 הודה ובירושלם "Judah and Jerusalem"; not found in Neh.'s own writing.

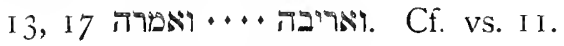

13, I9 ירושלם 1989. Compare this verse with 7, 3.

יצנצ. Mentioned in 4, I0. I7; 5, I0. I6. It may seem strange that the Chr. should have missed an opportunity of bringing in the Levites. This was however no regular 
service, but temporary police duty, of no great importance. The Levites appear duly in v. 22.

I3, 22 ללוים ... There can be no question concerning the authorship of this.

I3, 23 היהודים. It has already been remarked that the Chr. does not elsewhere make use of this term; there was a particular reason for employing it here, however, inasmuch as Jews and Ashdodites \&c. were put in direct contrast; as השדודית is in the following verse.

השיבו נשים elsewhere only in Ezra IO (five times). For the omission of the relaticic, see note on $S, I O$.

I 3, 24 אשרודית. How wide are we to suppose the difference between the language of the Jews and that of the Moabites, Ammonites, or Ashdodites? The reading of the text here does not give the impression that Neh. was taking these summary measures simply in the interest of a pure Jerusalem accent.

וכלשון עם ועם This is awkward enough to be the Chr.'s own; but is more probably a misplaced gloss intended to supplement שמדודית. The testimony of the Greek Mss. is all but unanimous against it.

13, ואריב עמם As in vs. II. 17.

וזמרטם Cf. Ezra 9, 3.

אם תתגו וגו. The same formula in IO, 3I; Ezra 9, 12. וี See note on Ezra 9, 2.

I3, 26. Cf. vs. IS; also 9, $26 \mathrm{ff}$; Ezra 9, $6 \mathrm{ff}$; 2 Chr. 29, 5-9; 30, 7. 8 \&c.

I3, הנשמע Cf. Cf. the very similar rhetorical question

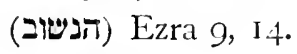

למעל See note on Ezra 9, 2; and cf. Ezra IO, 2. 10!

להשיב נשים נכריות. Exactly as in Ezra 10, 2. 10.14. I\%. IS. See note on vs. 23. 
13, 28 אלישיב. See note on vs. 4. The event alluded to here took place not long before the time when the Chr. wrote (Jos. Antt., xI, 8, 2); possibly within his own memory. See below.

וזברחהו. Cf. v. IO; I Chr. 8, I3; I2, I5. It should be plain from the way in which this is told, that the founding of the Samaritan church did not take place in the time of Nehemiah. He could not have dismissed the whole matter with this brief and obscure mention. On the other hand, the Clronicler, who is getting in a stab at the new sect (notice גמאלי הכדנה in the next verse) through the medium of Neh.;-could not have taken a better way to accomplish his purpose.

I3, להם To whom can this refer, as the story is told here?

על גאלי דבכהנה. Cf. 7,64 (Ezra 2,62), where the same expression occurs in slightly differing form (a verse certainly written by the Chr.). How this accusation could apply is not at all apparent from the prescut narrative; from the particulars given by Josephus-in an account derived from extra-Biblical sources, and by no means to be separated from the history in which it stands-the meaning of the allusion is at once plain.

ודהלוים. Once more.

I 3, 30. This verse betrays in almost every word the hand of the Chr.

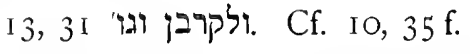

בעתים מומנות. A noticeable expression, occurring elsewhere only 10, 35; Ezra 10, 14.

The evidence thus presented seems to me to prove that the Chr. wrote the whole of ch. I3. That he was the author of vs. I-I4. 28-3 I there cannot be the smallest doubt (if his presence in Ezra-Neh. is admitted at all); the 
indications in the intervening section vs. $15-27$ are fewer, but conclusive nevertheless. As in the preceding cases, there is nothing in the text to justify the assumption that an older narrative was worked over, or that any paragraph or verse came from another source than the Chr.'s active brain. It does not appear that Neh. wrote anything more than the five chapters above assigned to him. His story is complete as there given; there is nothing to require or suggest its continuation further.

I append a tabular view of the results reached in the above analysis of Ezra-Neh. The Chr. made use of two documents: I. Nehemiah's own account of the building of the wall of Jerusalem. 2. An Aramaic writing composed probably near the beginning of the Greek period.

Nehemiah.

( $(372$ B. C.?)
Aramaic Source. (Near the end of the $4^{\text {th }}$ century.)

Ezr. 4, 9a.

4, IO (from בקריה) 8aß. Sb. II -23 .

$$
5, \mathrm{I}-6,8 .
$$

די יתב"ן The words must be restored before בקריה. At the end of the verse וכענת is a later addition. The mistake was occasioned by the resemblance to the end of vs. II.

Beihefte z. ZATW. II. Torrey, The Composition \&c.

\section{Chronicler.}

(After 300 B. C.)

Ezr. I, I-4, Sa $\alpha .^{x}$

4, 9b. IO (as far as המו (ד).

4,24 .

I After making a simple transposition of clauses in $4,6.7 .8$, as previously explained. 


Nehemiah.
(372 B. C.?)
Neh. I, I-2, 6.
2, $9 \mathrm{~b}-20$.
3, 33.
3, 34a $\beta-5,13 \mathrm{a}$.
5, I3b $3-6,19$.

Aramaic Source.

(Near the end of the $4^{\text {th }}$ century.)

Ezr. $6, \mathrm{II}-\mathrm{r} 4 \mathrm{~b} \beta$.
Chronicler.

(After 300 B. C.)

Ezr. 6, 9. Iо.

$6,14 \mathrm{~b} \gamma-8,36$.

Neh. 7,70 -8, I 8 .

Ezr. 9, I-IO, 44.

Neh. 9, I-IO, 40.

2, 7-9a.

$3, \mathrm{I}-32$.

$3,34 \mathrm{a} \alpha$.

5. I $3 \mathrm{~b} a$.

$7, \mathrm{I}-69^{2}$.

I I, I-I 3, 3I.

I 69 in Baer's edition.

268 in Baer's edition.

That the form of the text thus restored is that of the original Ezra-Nehemiah, I should be the last to admit. On the contrary, our canonical book is a mutilated version, in which the Aramaic Story of the Three Pages, which was interpolated at an early date, has been cut out again, together with a part of the original narrative, leaving a very noticeable gap between ch. I and 2. This I hope to prove elsewhere. There are also minor omissions which may be supplied from I Esdras, which on the whole represents an older form of the Hebrew text, for the portion it covers, than that which we have, though itself 
much more carelessly written ${ }^{\mathrm{I}}$. For the most part, our Hebrew text has come down to us in good condition and almost wholly free from additions. I have above noted

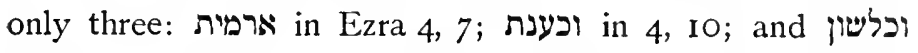
עם ועם in Neh. 13, 24. I have observed, but not thought it necessary to mention, several more; due in every case to scribal blunders, dittography, and the like. In many cases where literary taste seems to demand purification of the text, the trouble is due simply to the writer's peculiar style. No one who is familiar with the writings of the Chronicler could feel justified in marking verses, or clauses, or even single words, as later additions to the work of that author merely because they are superfuous or disarrange the context. Awkward parentheses and suspended constructions are among his specialties. It is not probable that the book was at first widely copied or read (see below). Those who would be likely to alter Hebrew canonical writings in the interest of a theory or for harmonistic purposes would be least likely to wish to alter this book. The Chronicler had cared for that.

\section{The Historical Content of Ezra-Nehemiah.}

The results reached in the preceding investigation will, if accepted, necessitate a decided change in our estimate of the value of Ezra-Nehemiah as a source for the postexilic history of the Jews. It has been my aim to show: I. That the method pursued by the Chronicler in writing this part of his book is precisely the same as that observed by him in the previous portions of his history, from Adam to the Exile. He incorporates his documentary

I It is my intention to make a detailed comparison of the two recensions, in the near future. 
sources entire, so far as practicable, not rewriting them or working them over, but enriching them occasionally with an added clause or inserted paragraph; and supplements them with considerable narrative matter of his own composition. 2. That the older documents here incorporated by him are of much less extent than has been generally supposed. The question of the trustworthiness of the Chronicler's narratize thus gains considerably in importance, and it is with this that I shall chiefly concern myself. It is possible to be brief here. No fact of $\mathrm{O}$. T . criticism is more firmly established than this; that the Chronicler, as a historian, is thoroughly untrustworthy. He distorts facts deliberately and habitually; invents chapter after chapter with the greatest freedom; and, what is most dangerous of all, his history is not written for its own sake, but in the interest of an extremely one-sided theory. In passing judgment on his account of the Ezra-Nehemiah period, it is only necessary to inquire: I. what part of his narrative receives confirmation from other sources; and 2. what is the nature of such sources, and the character of their testimony. Where his account is not supported by any other witness, the matter is settled, strictly speaking, without further discussion. It may not be superfluous, however, to examine briefly the internal character of his narrative in a few such cases.

As for the story of the Return under Zerubbabel, told in Ezra I. 2, each one of its several features has been repeatedly shown to be unworthy of credence. The Cyrus edict cannot possibly be regarded as genuine. Even the Aramaic document knows nothing of Zerubbabel as governor in the time of Cyrus (see 5, I4-I6). ${ }^{x}$ The mention of Sheshbazzar in ch. I is a transparent harmonistic device. ${ }^{2}$

I The Chr. avoids using the term "governor", to be sure. See below.

2 How well it succeeded may be seen e. g. in 1 Esdr. 6, I7! 
The list in ch. 2, whatever may be thought of its origin ${ }^{\mathrm{I}}$, is evidently not an authentic list of returning exiles. See Kosters, op. cit., p. $32 \mathrm{ff}$.; Wellhausen, Israel. u. juid. Gesclichte $^{2}$, p. I 55 . Kosters ${ }^{2}$ has demonstrated, from the testimony of Haggai and Zechariah, that Zerubbabel and Joshua were not returned exiles; and furthermore, that the prophets $H$. and $Z$. know nothing of an important return of exiles from Babylonia.3 The later references to this 3 , found in Ezra-Neh., are all by the hand that wrote Ezra I. 2 (Ezra 4, 12, which is a disputed passage, may be left out of the discussion for the present). ${ }^{4}$ According to the representation of this writer, Jerusalem was uninhabited when the exiles returned. $\mathrm{He}$ does not say this in so many words, but it is the necessary inference from his absolute silence regarding any "remnant"s, and is quite in keeping with his idea of post-exilic Israel, for which הגולה is a synonym. ${ }^{6}$ His theory, as it appears all through Ezra-Neh., is that the population of Jerusalem and the surrounding towns was entirely swept away by the Chaldaeans. These cities and villages then remained desolate until the return, when "the priests and the Levites and the porters and the singers and the Nethinim and all Israel" had simply to go and take possession of them and occupy them as they

I I shall discuss below the question of the origin of these lists.

2 Op. cit., p. $\jmath^{S} \mathrm{ff}$.

3 Cheyne, Introd. to Isaiah, IS95, p. XXXV f., accepts and supports this conclusion of Kosters.

$4 \mathrm{Ch} .5,13-16$ omits all mention of the company that came with Sheshbazzar. The omission is noticeable. Cf. also 6,3 ff.

5 Contrast Neh. I, 2 f.!

6 In particular, $3, S$ leaves no room for any survivors from the

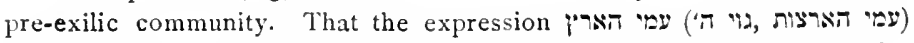
is intended to refer to this remnant left in the land (Reuss cannot be successfully argued. See below. 
pleased. ${ }^{x}$ Such a representation as this hardly deserves serious refutation. In a word, the story of the return in the time of Cyrus has no credible testimony whatever in its favor; while there is weighty evidence against it. ${ }^{2}$

The continuation of the history in $3, \mathrm{I}-4,5$, describing the building of the altar and the beginning of work on the temple, is of the same character. Since Schrader's demon-

I Just as in the Priestly narrative of the conquest of Canaan the heathen are completely exterminated at a blow, and the Israelites have only to cast lots for the empty land.

2 It is still possible to argue, as Wellhausen does (Nachrichten der Königl. Gesellsch. der Wissenschaften zu Göttingen, I\$95, p. I $8_{3}$ f.; Israel. u. jiid. Geschichte 2 , p. I55, I60), that a return at about this time is intrinsically probable, inasmuch as $\mathrm{I}$. Jerusalem was entirely destroyed, and the population swept away, by the Babylonian army; 2. Is. $40 \mathrm{ff}$. gives the impression that Jerusalem is desolate and without inhabitants (i. e. shortly before the time when this return of exiles is supposed to have taken place); 3. Nevertheless, in the time of Haggai and Zechariah Jerusalem is occupied by people in prosperous circumstances, with laws and rites quite like those of the Priest-code, and with a literature of their own, not Babylonian, but Palestinian, in its character. Ergo, there must have been a return of exiles.

To this may be said in reply: The accounts of the destruction of the city, and deportation of the inhabitants, are certainly very much exaggerated. As for the number carried to Babylon, even Jer. 52, 28-30 gives the total as only 4600 , which is much more likely to be an exaggeration than the reverse. From the highly colored poetic utterances of such a writer as the author of Is. 40 ff. no legitimate argument on this point can be derived - nor could be, even if his language were much more definite than it really is. Wellhausen himself admits (Nachrichten, p. 185): „Man hat die Deportation vielfach als zu radikal angesehen..... Dem entsprechend hat man denn auch bei der Restauration zu sehr ausser Acht gelassen, dass doch ein starker Bodensatz der alten Bevölkerung sich noch im Lande vorfand." After this admission, there is little left on which to found the theory. The absolute silence of all the prophets, even Haggai and Zechariah, on the subject of a return of exiles in any considerable number, taken in connection with the condition of things in Jerusalem presupposed in Haggai, Zechariah and Malachi - our earliest witnesses from the city after its capture by the Chaldaeans - must be regarded as furnishing very straightforward evidence 
stration ${ }^{\mathrm{I}}$ there is no need of further proof that the narrative here is utterly unworthy of credence. It is to be noticed with what an appearance of reality it is all told. The events are dated, even to the day of the month ${ }^{2}$; names of persons are freely used; and in vs. IO-I 3 we have a bit of vivid description in the Chronicler's characteristic style.

Of the Aramaic document, 4, 8-6, I4, and its worthlessness as a historical source, I have already spoken at some length. (See above.) The condemnation applies not only to $4,8-23$ (Kosters), but to all the rest as well. It is admitted on all hands that the "official documents" here presented cannot be regarded as genuine. In recognizing this, emphasis should be laid not only on the motive so apparent in all five of these documents alike, but also on the fact that this Aramaic section contains almost nothing else. It must be evident that the writer did not introduce the documents for the sake of the history, but rather the history (only a few bits of the barest narrative) for the sake of the documents. There is no legitimate use that can be made of such a work as this in constructing a sober history of the period, except in cases where its statements are confirmed from reliable sources. The main facts with which it deals are the following: I. The Cyrus edict, and the laying of the foundation of the temple by

that the post-exiiic community in Jerusalem grew up from the survivors of the pre-exilic community, namely, those who remained in the city when it was sacked, reenforced by those who would be certain to come in from all directions as soon as the danger was over. To argue that these survivors must have all belonged to the lowest stratum of the people, and have been therefore incapable of preserving the religious and literary traditions of Jerusalem, is to beg the whole question.

I L. c., p. $4 \mathrm{~S}$ I ff.

${ }^{2}$ Ch. 3,8 is no exception. I Esdras $(5,54-56)$ has preserved the original reading, beyond all question. 
Sheshbazzar. 2. The attempt to build the wall, and its interruption by enemies, who secure a decree from Artaxerxes ordering the work to cease. 3. The completion of the temple by express command of Darius, and in spite of interference from Persian officials. As for the story of Cyrus' decree regarding the temple and the vessels, Kosters (p. 27) is undoubtedly right in explaining it as a fiction derived from Is. 44,$28 ; 45, \mathrm{I}$. The official execution of the royal decree by Sheshbazzar formed a necessary part of the story. ${ }^{\mathrm{I}}$ As this feature, the founding of the temple by a heathen, was obnoxious to the Chronicler, he managed to get rid of it in his own account, as we have seen. There is evidently nothing to be learned from the book of Ezra regarding the time when the work of building the temple was first begun. The date given here-the beginning of the reign of Cyrus-was equally necessary to the story derived from Is. $44 \mathrm{f}$. and to the Chronicler with his theory of the return from the exile. ${ }^{2}$ Concerning the completion of the temple we are no better informed. There is the best of evidence that work was begun under Zerub-

I The fact that the name Sheshbazzar "sounds genuine" is far from proving that the statements here connected with it have any basis of fact. Why is it difficult to suppose that Jewish story tellers occasionally recognized the difference between native and foreign names? And there would be every reason for believing, even if we had not the books of Daniel and Esther, that Babylonian and Persian names were to be had when they were wanted.

2 We should suppose, on general grounds, that at least a temporary house of worship (Hag. 2, 14; cf. Zech. 3, S, \&c.) would have been erected long before the time of Cyrus. The great undertaking in the time of Ilaggai and Zechariah would then have been to stir up the people to build a worthy structure in place of the poor make-shift. On this supposition, the words of Hag. I, 2-6 take on new meaning. In the difficult passage Hag. 2, 15-19 there is at least nothing to prove the contrary (in 2, 16 read, with LXX, מִּי הִיע "How fared it with you?" For the idiom, cf. Ruth 3,16 ). 
babel in the second year of Darius (I); beyond this, we are limited, unfortunately, to the statements of the Aramaic document, 6, I4, and the Chr. (with the usual date), 6, I 5; and on these, as on the stories of hostile interference, 4, I- 5 and 5, 3 ff., no dependence can be placed. The episode of Tatnai and his associates is introduced as means to an end; namely, the glorification of the Jews and their worship in the long letter that follows, and especially in the edicts of Cyrus and Darius, 5, $8-6, \mathbf{1 2}$. The story told in $4,8-23$ is of a like nature. The statement that the Jews made an early attempt to build the city wall, but were hindered, is not in itself hard to believe, nor can it be fairly claimed that it is contradicted by other evidence. ${ }^{x}$ Only the character of the source from which it comes debars us from making any confident use of it. In fine, there is nothing in this Aramaic writing to render it probable that the author had at his command any other source than the books of Haggai and Zechariah.

The story of Ezra is the Chronicler's masterpiece. It is the best exemplification of the traits that appear so prominently in the long passages in the book of Chronicles, his own qualities as a writer of fiction and his idea of the history of Israel. The story of the return under Ezra is in most respects a repetition of the former account, of which Zerubbabel was the hero. As that expedition signified the restoration of the Jewish community and the building

I With Kosters' argument (l. c., p. 5 f.) that Neh. 1, I f. does not refer to a definite calamity that had recently befalien the Jews, I am in full agreement, however. Even Kosters fails to enter a protest against the wholly unwarranted assumption, now in such favor, that Ezra $4,21-23$ implies a destruction(:) of the part of the wall that had been built. It is plain, moreover, that neither the Aramaic writer nor the Chr. identified the Artaxerxes of Esra 4 with the one mentioned in Neh I ff. See above. 
of the temple, so this second layer of exiles is designed to complete the work thus begun, and give the religious institutions their final form. The narrative shows the same unhistorical features that were seen in the case of the other. The Artaxerxes letter, 7, $12-26$, is a transparent imitation of the letters (themselves fictitious) in the preceding chapters ${ }^{x}$, and stands on the same plane with the Cyrus proclamation in ch. I, which it resembles in several particulars. When the members of this expedition arrive in Jerusalem, they are at once absorbed in the community, and are not again mentioned or thought of as in any way distinguished from the rest. ${ }^{2}$ Here, again, the remnant left in the land at the time of the Babylonian captivity is wholly ignored. See for example Ezra 9, I. 4, \&c. The only occupants of the land are the members of the two expeditions from Babylonia (called collectively the גולה) 3, and the עמי המרצות. These last-named, whatever their origin, are heathen, the legitimate successors of "the Canaanite, the Hittite, the Jebusite", \&c. (Ezra 9, I ; cf. vs. 2. I I ; 6, 2I, \&c.). That Jews left in the land cannot be intended here is shown especially in the chapters treating of the mixed marriages. And on the other hand, the members of the גid are the only sinners in the matter of the foreign wives, because there were no others who could thus sin! Either the Chr. really believed that "the Canaanite, the Hittite, the Jebusite", and so on, remained in the land until the end of the fifth century (!), or else he is transferring to Ezra's time a condition that existed in his own day. In that case he would

I In vs. I2 שלם has accidentally fallen out after wמי Cf. 5, 7. The emendation is so obvious that it is strange no has made it.

2 Against Kosters, l. c., p. 97 and elsewhere.

3 The way in which this term is used by the Chr. as an exact synonym for "Israel" is well illustrated in Ezra Io, 8. 
probably have found it difficult to explain just what he meant here by the expression עמי הארנות.

The central point in the story of Ezra is the account of the restoring of the Law. This was the main object of his coming from Babylon (see above). The members of his expedition, on their arrival at Jerusalem, disperse to "their" respective cities, where they remain until it is time for them to assemble with the rest of Israel to hear the Law read. The account of this ceremony is cast in the same mould as the stories told by the Chr., on his own authority, concerning his other favorites, David, Solomon, Hezekiah and Josiah. In particular, the story of the dedication of Solomon's temple, I Ki. 8; 2 Chr. 5-7, furnishes a striking parallel to Neh. 8 , and might well be supposed to have served as the model. The children of Israel assemble in the seventh month (2 Chr. 5, 2. 3). A brazen platform, or pulpit, has been prepared; and Solomon, mounted upon it, conducts the ceremony (6, 13; not in Kings). As he blesses the people, all stand $(6,3)$. The long prayer which follows is made up largely of Deuteronomic phrases (6, I4-42). After the ceremony, all disperse and keep the feast with joy $(7$, S. 9).

To the question whether there may not have been some facts at the basis of this story of Ezra and the Law, the answer, so far as any can be given, must be in the negative, for the following reasons: I. Because of the improbability of the story itself. It is a kind of narrative of which we have abundant examples in the so-called "priestly stratum" of the O.T. The representation is mechanical and unnatural to the last degree. It is understood in Babylonia that Ezra is to proceed to Jerusalem and reinstate the Law, as an officer would serve a writ. Jerusalem was a city of some size, with rulers, nobles (Neh. 2, 16, \&c.; cf. I, 2), 
native priests (Zech. 3,8 , \&c.), a population partly, at least, in very good circumstances (Hag. I, 4), and with old and well established religious traditions. But Ezra conducts matters with a high hand, and the people of the city, priests and laymen alike, stand huddled together like frightened sheep while the ceremony of "restoring the Law" is being carried through. This is the Chr.'s own way of manufacturing history. To suppose, as is now commonly done, that a new law-code was introduced (i. e., made canonical) on this occasion involves still greater difficulties. It is not in itself a probable theory that the Priestly Law should have been written or edited in Babylonia; and there is certainly nothing in the law itself that could be regarded as proof of such an origin. The sole witness to this theory is the story told in Ezra-Neh. As for the way in which the Law came to be regarded as sacred and binding, it may be that there are those who can see how it would be easier for Babylonian priests to suddenly foist a "canonical" law-code upon the people of Jerusalem, than for native priests gradually to gain for it its place of authority. 2. The second reason for believing that the Ezra story has no basis of fact need only be stated. It is because of what we already know concerning the Chr.'s talent for manufacturing just such stories in favor of his own view of the history of Israel. The wealth of incident with which the narrative is set forth (e. g. Neh. S, 4; Ezra IO, 6. 9) will not deceive those who have read the Chronicles. ${ }^{\mathrm{I}}$ 3. The motive for composing such a story at this point in the history is especially plain to see. The Law was carried to Babylonia with the children of Israel. Now that the temple was rebuilt, and it was once more possible to observe

I Cf. also Wellh., Proleg.4, p. 353 . 
the Law, it was fitting that it should be brought, with due ceremony, to Jerusalem. ${ }^{x}$ It had been sadly neglected, moreover, and here was the opportunity to exhibit the fact in a most impressive way. It was necessary, too, to create a fitting character to do this work. Nehemiah could not be used for the purpose; for he was not suited, either by birth or by profession, for the task; besides, everybody knew who he was and what he had done. To a history written from the standpoint of this one, an Ezra was indispensable. $^{2}$ The Chr. certainly took the simplest and most direct way to provide one, concerning himself only with the immediate object, and leaving the rest to his readers. A lineal descendant of Aaron, an "expert scribe" 3 , the absolute power of a dictator-these were the necessary properties of the character. 4. A fourth reason is derived from the significant silence concerning Eara in Sirach 49, I I-I 3 (written about I So B. C.?). The more carefully one reads this long hymn (ch. 44-50) in praise of the names revered in the Jewish church, the more remarkable the omission of Ezra seems. Zerubbabel, Joshua and Nehemiah receive appreciative mention. Notice also the writer's enthusiasm over Josiah and his reforms, 49, I-4. It is hardly credible that Bar Sira, with his zeal for the

I Similarly, in certain favorite Jewish legends the sacred fire is kept safe in Babylonia until its restoration (by Nehemiah, 2 Macc. I, $20 \mathrm{ff}$.).

2 Just as an Asaph was required by the Chr.'s theory as to the Temple music.

3 Throughout the narrative, Ezra is represented as a "scribe" in the later technical sense of the term; one learned in the Law, and

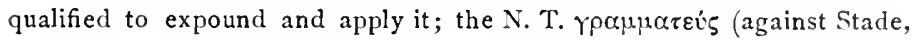
Gesch. II. p. I40, note). In Ezr. 7,6 he is introduced as

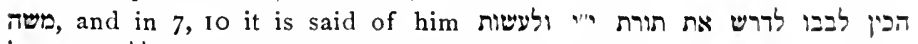
וללמר בישראל A And this conception of his relation to the Law is consistently maintained. See also Carpzov, Introl., I. (1757), p. 308 . In

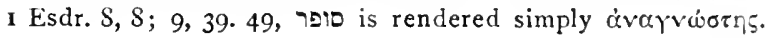


Jewish Law, should have intentionally slighted Ezra; the one satisfactory explanation of his silence is, that he had never heard of him. And this is in every way probable. The Chronicler's book of history was not one that would be often copied or widely circulated. ${ }^{x}$

The account of Ezra's social reforms is quite as destitute of any internal probability or external support. The inhabitants of Jerusalem here presented to us are puppets, made to act according to a theory (as in Num. $3 \mathrm{I}$, Judg. 20 f., I Chr. I3, \&c.), not men and women of flesh and blood. The monstrous proceeding described in Ezr. 9. IO $^{2}$ would be sufficiently incredible even if it were demanded by the Jewish Law, which is not the case. Race exclusiveness is not brought about suddenly and violently, by a wave of the hand. Whether the Chr.'s purpose in this part of his narrative was to account for this same exclusiveness, or to work in its interests, or to deal a blow at the founders of the Samaritan church, need not here be conjectured.

Before leaving the story of Ezra and his expedition, a word more may be said about the Jewish tradition of a return from the Babylonian exile. The fact deserves to be emphasized, not passed over lightly, that outside of Ezra-Neh. there is not a trace of any such tradition in the Old Testament. To the prophets, Babylonia is not the only land of captivity. The "exiles" of whom they speak are scattered among all the nations (Is. 43, 5. 6; 49, 12; Zech. 7, I4; 8, 7, \&c.). The cherished hope seems to be

I It may be worth mentioning, in this connection, that in 2 Macc. I, IS-36, Nehemiah, not Ezra, is the one who restores the worship (Renan, Histoire, IV. p. 97).

2 It is represented as completely successful, Neh. $9 \mathrm{f}$. being the immediate sequel of Ezr. IO. See above. 
that the Jews of the Diaspora who have left the holy land, and suffered strangers to pour in, will one day return (Joel $4, \mathrm{I} / \mathrm{b})$. But there is nowhere a hint that this hope was ever realized in any actual occurrence. Such an event would have furnished a most inspiring theme for a Psalmwriter, or could have been used with great effect in the prophet's prediction; but we look in vain for anything of the kind. ${ }^{x}$ With the exception of the single clause in Ezr. 4, 12 (in the Aramaic Document), eicry mention of a return comes from the Chronicler. While there is nothing improbable in the supposition that the Chr.'s extravagant theory of the exile and the restoration was inherited, in fully developed form, by him; yet in view of the silence of Ezr. 5, 13-I6; 6, $3 \mathrm{ff}$. with regard to a return of exiles (see above), it seems to me more probable that the clause in 4,12 is an interpolation by the Chr.

The principal additions made by the Chr. to the genuine memoirs of Nehemiah are lists of names. The general character of some of these has already been briefly noticed above; it remains to ask whether any use can be made of any of them. Even an untrustworthy writer may sometimes give us valuable information. But concerning these lists in Ezra-Neh. (for all belong in the same category) there is only one answer that can be given. There is nothing to make it probable that any one of them was derived directly or indirectly from official sources; while on the other hand there is no lack of indications that we have in them merely worthless compilations. A comparison of these lists with one another and with those in I Chr. leaves the impression made by looking into a kaleidoscope, though without the element of regularity, for the same broken bits

I In the book of Tobit $(14,5)$ we have at last the tardy mention. 
are jumbled together in many different ways. Compare e. g. Ezr. 2 (Neh. 7, 7-68) with Neh. II, noticing the context (see above). Cf. also I Chr. 9, 2-I7 with Neh.

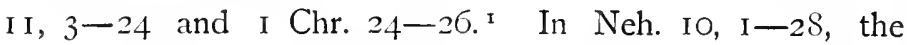
writer is apparently speaking of individuals; but a comparison of $7,8-43$ and $I 2, I-2$ I seems to require us to suppose that he is referring to families or classes. Besides this economy of material, which is in itself more than suspicious $^{2}$, there are contradictions and impossibilities in the Chr.'s lists, of such a nature as to confirm the impression that he alone is responsible for them. For characteristic examples, see Graf, Geschichtl. Biicher, p. $230 \mathrm{ff}$; Wellhausen, Prolegomena 4 , p. 220 ff.; Smend, Listen, p. Iof.; Kosters, Wiedcrherstellung, p. 3S, 4O. The fondness for inventing such tables and catalogues as these has played a very conspicuous part in the world's literature. 3 Knowing the Chr.'s qualities as a historian, and that the tendency just mentioned is especially strong in him, only one course is open to us; namely, to refuse to make any use of these lists. Neh. 3 is on the same footing with I Chr. I2.

The unhistorical character of Neh. 12, 27-13, 3I has already been shown, in connection with the analysis. Nehemiah, so far as we are able to judge from his own memoirs, was a man of affairs, and one not likely to concern himself with the things that are most interesting to the Chr. He did institute certain reforms, however (ch. 5), and it was possibly this fact that led the Chr. to make him a reformer after the pattern of Ezra (see note on I3, I5) and a special patron of the Levites.

I See Smend, Die Listen, p. 7.

2 Cf. especially Graf, Geschichtl. Bücher, p. 242 f.!

3 See the interesting illustrations in Bernheim, Historische Methode2, p. $272 \mathrm{ff}$. 
The evidence furnished by $13,28 \mathrm{f}$. with regard to the founding of the Samaritan church is important as corroborating the story told in Jos. Antt. xI, S, so far at least as the date is concerned.

It is unfortunate that we should be left in doubt as to which king Artaxerxes was Nehemiah's benefactor. According to the tradition represented by the Aramaic Document and the Chronicler, it was Artaxerxes II. (Mnemon), who reigned $404-358$ B. C. This is certainly testimony of the most unsatisfactory kind, but it is all that we have.

The result of the investigation as to the historical content of Ezra-Neh. has thus been to show, that aside from the greater part of Neh. I- 6 the book has no value whatever, as history. It may have served a useful purpose in its own day. The Chr. was not trying to write history for us, but for what he supposed to be the benefit of his people. He had his own motive, which we shall do well not to judge harshly. But his work, whatever else may be said of it, certainly throws no light on the history of the Jews in the Persian period. 
Druck von W. Drugulin in Leipzig. 
Gaylord Bros.

Makors

Syracuse, N. Y.

PAI. JAN. 21, 1908

Date Due

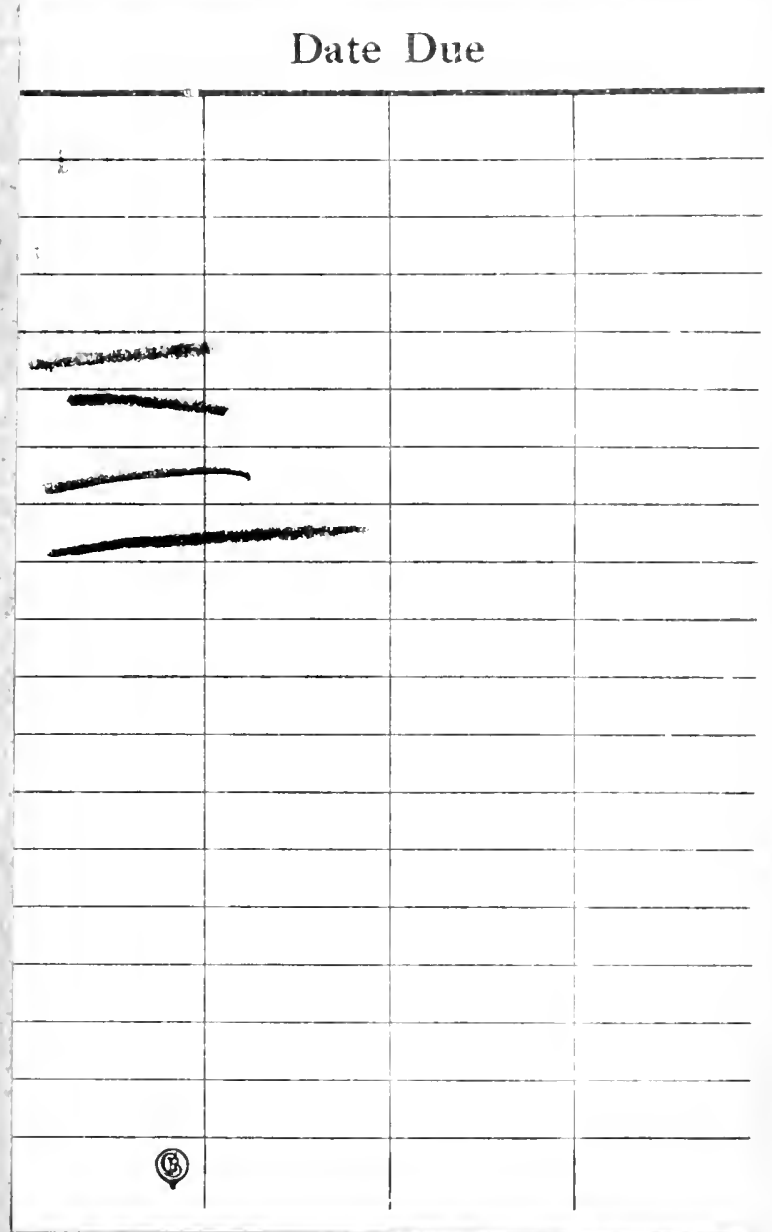


